\title{
Magmatic characteristics and geochronology of Ordovician igneous rocks from the Cadia-Neville region, New South Wales: implications for tectonic evolution*
}

\section{R. J. SQUIRE ${ }^{\dagger}$ AND A. J. CRAWFORD}

ARC Centre of Excellence in Ore Deposits and School of Earth Sciences, University of Tasmania, Private Bag 79, Hobart, Tas. 7001, Australia.

\begin{abstract}
The Ordovician volcanic and intrusive rocks of the Cadia-Neville region, in the southern Molong Volcanic Belt section of the Macquarie Arc in central-western New South Wales, display a temporal progression from shoshonitic basaltic volcanism (e.g. Mt Pleasant Basalt Member) in the late Darriwilian to Gisbornian (ca 460-453 Ma) to small-volume dacitic medium-K calc-alkaline magmatism (e.g. Copper Hill-type dacite) in the late Eastonian to early Bolindian (ca 450-445 Ma) to large-volume, high-K calc-alkaline to shoshonitic, mafic to highly evolved magmatism (e.g. Nullawonga Latite Member and Cadia Intrusive Complex) at about 445-440 Ma. The two episodes of shoshonitic magmatism are separated by at least 15 (but up to 20 ) million years, during which time limestones, associated with regional uplift, were deposited broadly coincident with emplacement of the medium-K calc-alkaline dacitic intrusions. Despite this, the lavas and intrusions associated with both episodes of shoshonitic magmatism have strikingly similar geochemistry, indicating that a similar mantle source and partial melting processes were involved over this time interval. The arc-type geochemistry of the volcanic and intrusive rocks in the Cadia-Neville region is very similar to the lavas and intrusions forming the Pliocene Tavua Caldera in Viti Levu, Fiji. The Pliocene shoshonitic rocks at Tavua Caldera were emplaced following cessation of arc magmatism when the arc moved into an extensional phase. By analogy with the Pliocene tectonic setting in Fij, the arc-like signature of the Ordovician magmas of the Macquarie Arc may be due to preprocessing of the mantle above a subduction zone prior to extension and fragmentation of arc lithosphere that led to generation of the subduction-modified shoshonite-dominated magmas.
\end{abstract}

KEY WORDS: Forest Reefs Volcanics, geochronology, Lachlan Orogen, Ordovician, shoshonite, tectonics.

\section{INTRODUCTION}

The Ordovician to early Llandovery (herein simply referred to as the Ordovician) volcanic and intrusive rocks of the central-western New South Wales section of the Lachlan Orogen, comprising disrupted fragments of the Macquarie Arc (Glen et al. 1998), include abundant high-K compositions, with strong enrichment of large ion lithophile elements (LILE) and light rare-earth elements (LREE), and low high field strength element (HFSE) contents that compare closely with the shoshonite rock association. The shoshonitic compositions of these Ordovician volcanic and intrusive rocks have been used to support tectonic models that involve magmatism either unrelated to subduction (Wyborn 1992) or accompanied by coeval subduction (Glen et al. 1998; Blevin 2002; Holliday et al. 2002). Understanding the significance of the shoshonitic magmatism is, therefore, critical for interpretation of the Ordovician tectonic setting. In a companion paper to this (Squire \& McPhie 2007), we describe the Ordovician lithostratigraphy and volcanic evolution of the Cadia-Neville region in the central part of the Molong Volcanic Belt in centralwestern New South Wales. Here, we describe the petrographic, geochemical and temporal variations of the Ordovician volcanic and intrusive rocks of the Cadia-Neville region (Figure 1). These new data provide a comprehensive knowledge of the temporal variations in magma compositions leading up to, and accompanying, formation of the Cadia-Ridgeway $\mathrm{Au}-\mathrm{Cu}$ systems.

\footnotetext{
*Appendices 1 and 2 [indicated by an asterisk (*) in the text and listed at the end of the paper] are Supplementary Papers; copies may be obtained from the Geological Society of Australia's website (http://www.gsa.org.au) or from the National Library of Australia's Pandora archive (http://nla.gov.au/nla.arc-25194).

${ }^{\dagger}$ Corresponding author and present address: School of Geosciences, Monash University, Vic. 3800, Australia

(rick.squire@sci.monash.edu.au).
} 


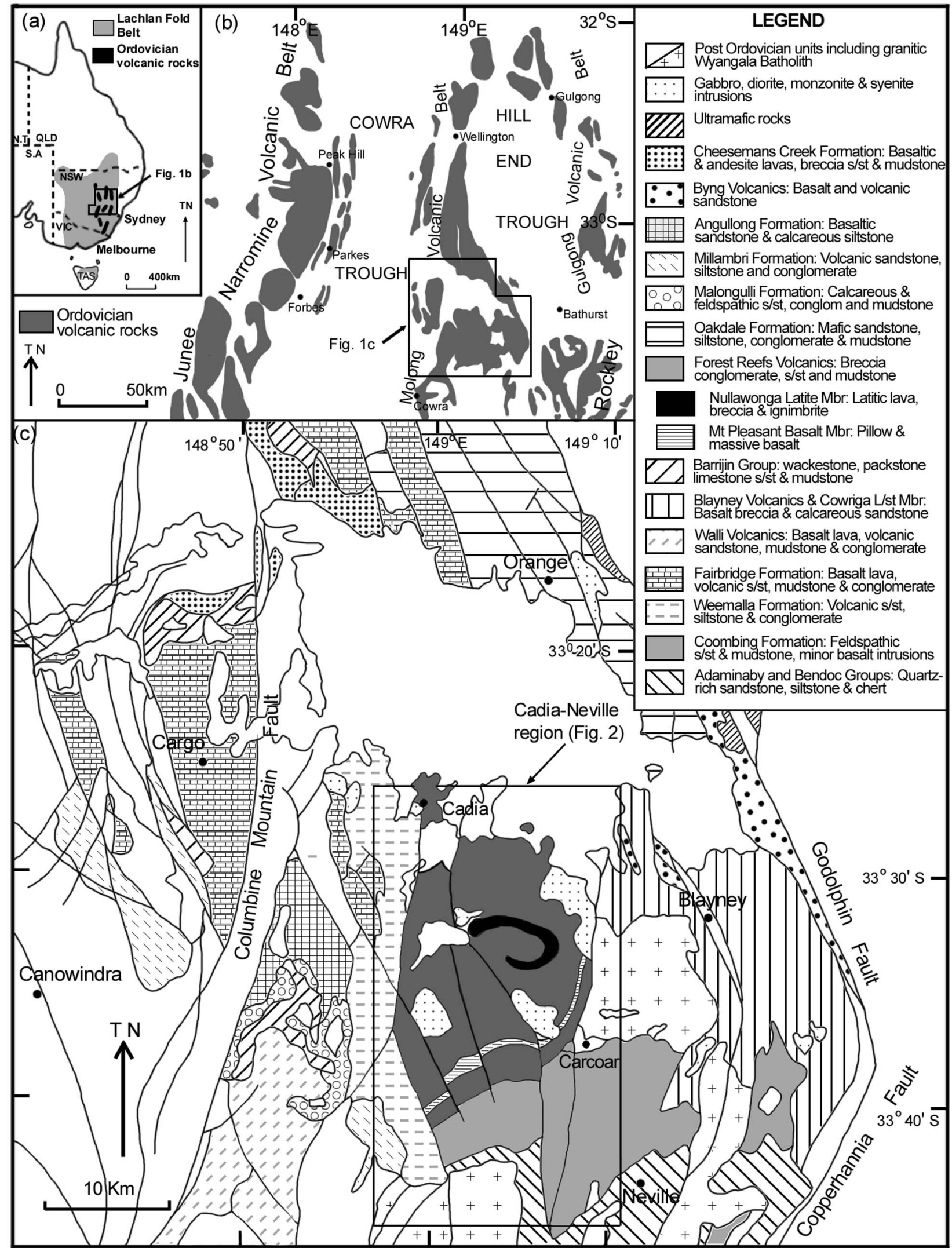

Figure 1 (a) Location of the Lachlan Orogen in eastern Australia, showing approximate distribution of the Ordovician volcanic belts. (b) Distribution of the three northernmost belts of Ordovician volcanic successions (Junee-Narromine, Molong and Rockley-Gulgong Volcanic Belts) and the Siluro-Devonian Cowra and Hill End Troughs. (c) Regional distribution of the principal stratigraphic units of the Molong Volcanic Belt and adjacent quartz-rich turbidites. Blank outlined areas are post-Ordovician units. Major faults and the location of study area (Cadia-Neville region) are also shown. Modified from Glen et al. (1998) and Raymond et al. (1998). 
We compare the southern Molong Volcanic Belt rocks with Pliocene shoshonitic volcanic and intrusive rocks from the Tavua Caldera, northern Viti Levu, Fiji. The geochemical similarities between Pliocene igneous rocks in Fiji and the Ordovician in New South Wales support the proposal that the Pliocene tectonic setting for Fiji represents a modern analogue for the Ordovician to early Llandovery tectonic setting of the Lachlan Orogen.

\section{GEOLOGICAL SETTING}

Glen et al. (1998) postulated that extension during the Early Silurian (Benambran Orogeny) resulted in the dismembering of a single Ordovician arc and arc-apron sequence, the Macquarie Arc. The Junee-Narromine Volcanic Belt has been taken to represent the original core of the arc, and the Molong Volcanic Belt and Rockley-Gulgong Volcanic Belt were interpreted to be the remnants of the large volcaniclastic apron with lesser volcanic centres, that had split from the arc during the middle Palaeozoic extension (Glen 1992).

The Molong Volcanic Belt is the central of the three major Ordovician volcanic belts in New South Wales, and is flanked to the east by the Early Silurian Hill End Trough and Mumbil Shelf, and to the west by the Cowra Trough (Figure 1). Details of the lithostratigraphy of the Molong Volcanic Belt are given in Squire and McPhie (2007) and Percival and Glen (2007). The feldspathic turbidites of the Coombing, Kenyu and Weemalla Formations represent the oldest known rocks in the southern Molong Volcanic Belt and have an inferred Middle Ordovician age (Wyborn \& Henderson 1996). East of the Carcoar Fault, the Coombing Formation is intruded by basaltic sills of the Eagle Hawk Basalt and is overlain by the Blayney Volcanics that include high-K calc-alkaline and shoshonitic lavas, and the shoshonitic Millthorpe and Byng Volcanics (Duerden 1999; Crawford et al. 2007). The Forest Reefs Volcanics conformably overlie the Coombing Formation between the Wongalong and Carcoar Faults, and the Weemalla Formation near Cadia (Figure 2). West of the Wongalong and Cadiangullong Faults, the Weemalla and Kenyu Formations are overlain by the Walli Formation and Cargo Volcanics, and include medium and high-K calc-alkaline lavas (Crawford et al. 2007).

The Forest Reefs Volcanics are a complex association of lavas, syn-volcanic intrusions and volcaniclastic facies (Wyborn \& Henderson 1996) considered to represent a volcaniclastic apron that onlapped and partly buried distal feldspathic turbidites of the underlying Coombing and Weemalla Formations (Squire \& McPhie 2007). The Forest Reefs Volcanics are divided into a lower and upper Forest Reefs Volcanics (Squire \& McPhie 2007). The lower Forest Reefs Volcanics are dominated by feldspar-rich sandstone and siltstone, volcanic lithic breccia and lesser black shale; polymictic volcanic conglomerate with sandstone matrix, and calcareous sandstone and siltstone facies are important near the top. The basaltic lavas of the Mt Pleasant Basalt Member occur near the base of the Forest Reefs Volcanics only in the southern part of the
Cadia-Neville region west of Carcoar, and represent the first manifestation of intrabasinal, shoshonitic volcanism in the Forest Reefs Volcanics.

The upper Forest Reefs Volcanics are inferred to unconformably overlie the lower Forest Reefs Volcanics and are taken to represent accumulation of a volcaniclastic pile at the distal part of a volcaniclastic apron. The shoshonitic trachyandesite facies of the Nullawonga Latite Member records a second phase of intrabasinal volcanism, and probably represents a relatively late phase in the accumulation of the upper Forest Reefs Volcanics. The Nullawonga Latite Member has been interpreted to represent the initial stages of a cone volcano (Squire \& McPhie 2007).

High-level intrusions were emplaced broadly contemporaneously with the Nullawonga Latite Member and have been separated here into highly porphyritic, and holocrystalline to equigranular phases. These range from narrow dykes to stocks and plutons up to several kilometres across. Together with the Nullawonga Latite Member, the majority of these units represent the plumbing system associated with a major volcanic centre, some of which may have been removed by erosion and thus have no counterparts among the sampled lavas. The monzodioritic to monzonitic suites are strongly porphyritic, show pronounced shoshonitic affinities (Wyborn 1992) and are also commonly associated with magmatic-hydrothermal $\mathrm{Cu}$ - $\mathrm{Au}$ mineralisation such as at Cadia (Holliday et al. 2002). The Burnt Yards Basalt, Gooleys Basalt, Sundew Basalt and the hornblende basaltic andesites are considered here to represent part of the same intrusive system, though Wyborn and Henderson (1996) interpreted the basaltic lavas of the Burnt Yards Basalt as recording the commencement of a second phase of volcanism in the Forest Reefs region.

\section{METHODS}

Some 163 samples of fresh rock collected from drillcore and surface exposures throughout the study area (Figure 3) were prepared by crushing about 700-1000 g in a steel jaw-crusher. Some $50-100 \mathrm{~g}$ of hand-picked fragments up to $0.75 \mathrm{~cm}$ across, free of oxidised or weathered rinds, veins or amygdales were blown clean with a compressed airgun and ground in a tungstencarbide ring mill (a ceramic mill was used for the ICP-MS samples) for about three minutes to produce rock powder $(<75 \mu \mathrm{m})$. Major and trace (Ni, Cr, V, Sc, Zr, Nb, Y, Rb, Sr, $\mathrm{Ba}, \mathrm{La}, \mathrm{Ce}, \mathrm{Nd}, \mathrm{Cu}, \mathrm{Pb}, \mathrm{Zn}$ ) elements (Appendix $1^{*}$ ) were analysed on a Philips PW1480 X-ray spectrometer at the University of Tasmania using several international and internal standards with each run. Major element analyses were recalculated to $100 \%$ anhydrous for plots and are reported as oxide weight percentages.

ICP-MS data for the rare-earth elements (REE) plus Zr, $\mathrm{Hf}, \mathrm{Nb}, \mathrm{Y}, \mathrm{Ta}, \mathrm{Th}, \mathrm{U}, \mathrm{Cs}, \mathrm{Tb}, \mathrm{Mo}, \mathrm{Sn}, \mathrm{Pb}$ and Sc have been obtained for a carefully selected subset of 38 samples representative of all major lithostratigraphic units (Appendix $2^{*}$ ). Two sample-preparation techniques were used. Samples of sparsely porphyritic Nullawonga Latite Member (samples 147798 and MB61) were prepared using a high-pressure (PicoTrace, $\mathrm{HF} / \mathrm{H}_{2} \mathrm{SO}_{4}$ ) digestion 


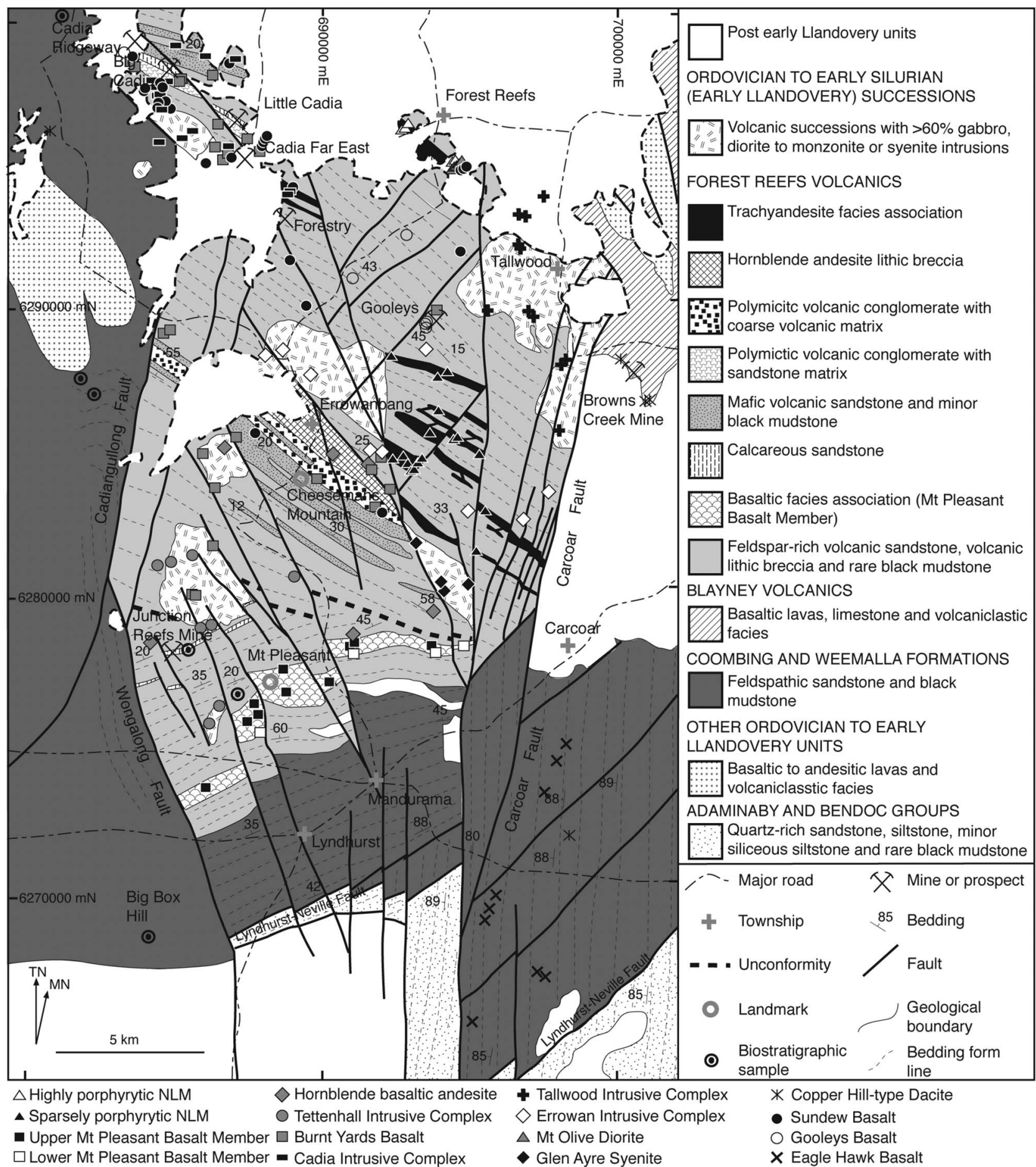

Figure 2 Revised geological map of the Cadia-Neville region showing the approximate location of whole-rock geochemical samples presented in this paper (see also Appendix $1^{*}$ ). Note that many of the samples collected in the northern part of the field area were from drillcore and thus appear to be located within Tertiary Basalt or Waugoola Group and thus do not correlate with the surface geology.

technique to ensure digestion of zircon, whereas the remaining samples were prepared using $\mathrm{HF} / \mathrm{HNO}_{3}$ in a Savillex Teflon beaker (Robinson et al. 1998; Yu et al. 2001). An Agilent HP model 4500 plus quadrupole ICPMS with HP ChemStation software was used along with a standard Babington nebuliser and Peltier-cooled glass Scott double-pass spray chamber.
Seven samples from selected lithostratigraphic units were analysed for $\mathrm{Nd}$ isotopes (six samples were analysed at the University of Adelaide and one sample analysed at La Trobe University) using an analytical procedure similar to that described in Waight et al. (1998) and a Finnigan MAT 262 Thermal Ionisation Mass Spectrometer in static mode. 


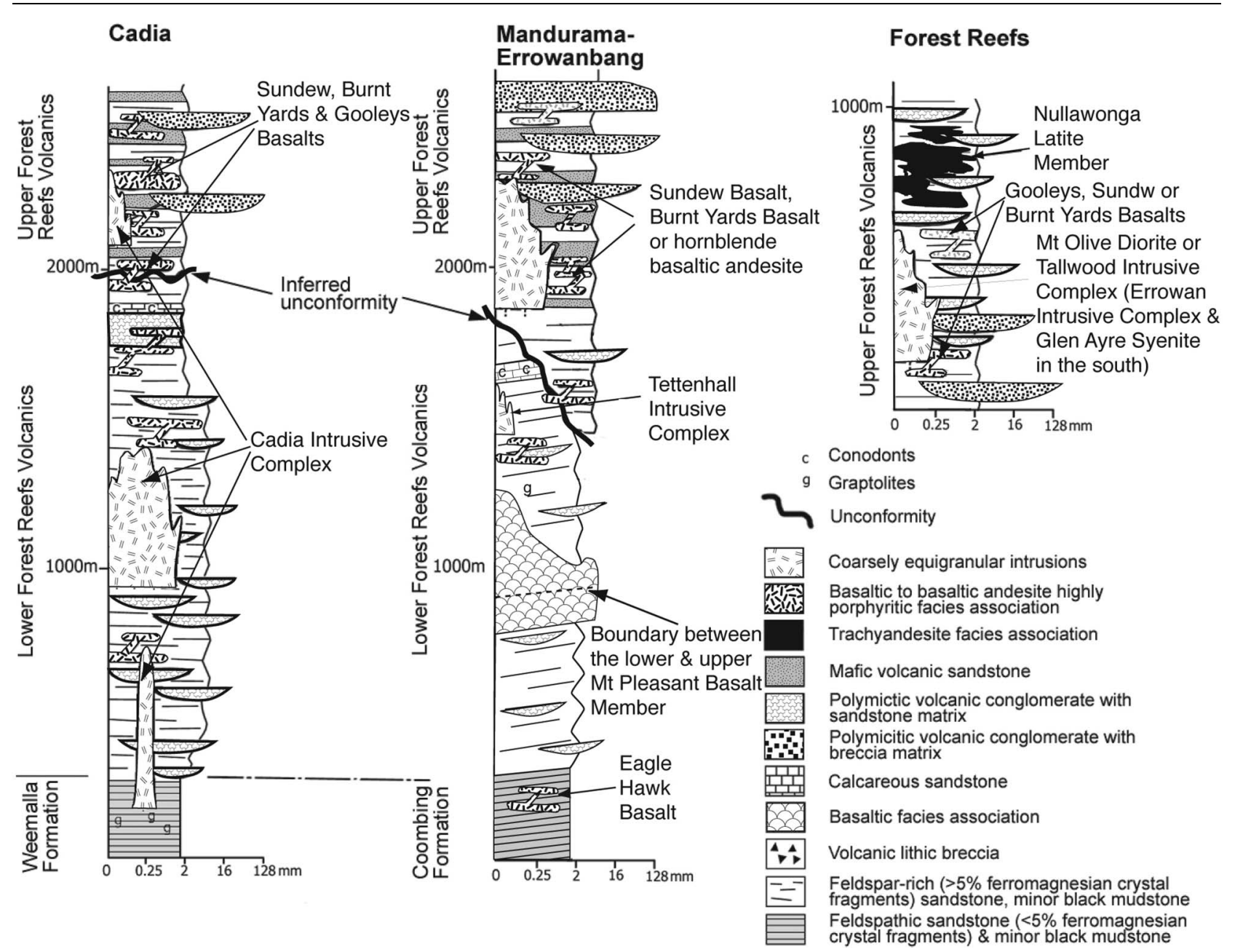

Figure 3 Schematic stratigraphic sections highlighting the similarities between the Forest Reefs Volcanics near Cadia and the Weemalla Formation defined by Wyborn \& Henderson (1996) located east of the Wongalong and Cadiangullong Faults (Figure 2). The volcanic successions in both regions contain similar-aged conodonts (c) in the calcareous sandstone and siltstone lithofacies (Packham et al. 1999) and broadly similar age graptolites (g) in the black mudstone facies near the base of the unit (see Squire \& McPhie 2007). Basaltic lavas of the Mt Pleasant Basalt Member are present only near Mandurama in the south.

Zircons for $\mathrm{U}-\mathrm{Pb}$ SHRIMP age dating were hand-picked from mineral concentrates prepared using standard crushing, desliming, heavy-liquid and paramagnetic techniques. They were then mounted in epoxy together with chips of the AS3 and SL13 reference zircons, sectioned approximately in half and polished, and reflected- and transmitted-light photomicrographs and cathodoluminescence SEM images were prepared to decipher the internal structures of the sectioned grains and to target zoned magmatic zircon areas. $\mathrm{U}-\mathrm{Pb}$ analyses were made using SHRIMP II and SHRIMP I, each analysis consisting of six scans through the mass range. Data were reduced in a manner similar to that described by Compston et al. (1992) and Williams (1998) with augmented uncertainties for the isotope ratios using the software of T. R. Ireland (see Muir et al. 1996). $\mathrm{Pb} / \mathrm{U}$ ratios were normalised relative to a value of 0.1859 for the ${ }^{206} \mathrm{~Pb} /{ }^{238} \mathrm{U}$ ratio of AS3 reference zircons, equivalent to an age of 1099.1 Ma (Paces \& Miller 1993). Uncertainties for individual analyses are at the $1 \sigma$ level; however, all uncertainties in calculated weighted mean ages are reported as $95 \%$ confidence limits.

\section{PETROGRAPHY}

All Ordovician rocks in the Cadia-Neville region contain alteration assemblages consistent with metamorphism to prehnite-pumpellyite and lower greenschist facies (Smith 1966). Hydrothermal alteration is locally intense (Holliday et al. 2002), and only carefully selected, least-altered samples were used for this study. Detailed petrographic descriptions are provided in Squire (2001), and here we provide only a brief description of the keys units.

\section{Mt Pleasant Basalt Member}

The Mt Pleasant Basalt Member is divided into two units: the basal and upper units (Figure 3). The basal Mt Pleasant Basalt Member is dominated by plagioclase, with minor clinopyroxene and rare apatite $( \pm \mathrm{FeTi}$ oxide) phenocrysts, whereas the upper Mt Pleasant Basalt Member contains a higher abundance of ferromagnesian phenocrysts (clinopyroxene \pm altered olivine), common FeTi oxides and generally less plagioclase, and apatite is absent. Alkali feldspar forms 
prominent rims on plagioclase phenocrysts in both the basal and upper units of the Mt Pleasant Basalt Member. The fine- to medium-grained, holocrystalline groundmass is composed of small laths of albitised plagioclase, granular clinopyroxene and tiny FeTi oxides.

\section{Nullawonga Latite Member}

The Nullawonga Latite Member is divided into sparsely porphyritic and highly porphyritic trachyandesite units. The highly porphyritic trachyandesite dominates the southern occurrences of this unit, whereas sparsely porphyritic trachyandesite is more limited in extent, occurring in drillcore near Forest Reefs and Cadia FarEast (Figure 3). Both units contain similar phenocryst assemblages, including plagioclase \pm clinopyroxene \pm apatite \pm biotite \pm sanidine \pm FeTi oxide; however, lower phenocryst abundances (usually much $<20 \%$ ) and more strongly developed flow banding occur in the sparsely porphyritic Nullawonga Latite Member and enable it to be easily distinguished from the highly porphyritic Nullawonga Latite Member ( $>30 \%$ phenocrysts). Alkali feldspar forms prominent rims on plagioclase, as in the Mt Pleasant Basalt Member. Small plagioclase laths dominate the fine- to medium-grained, holocrystalline groundmass. An irregular flow foliation is generally present, defined by aligned phenocrysts and irregularly shaped groundmass domains up to $15 \mathrm{~mm}$ long and $2 \mathrm{~mm}$ thick that contain radiating crystals, interpreted to be clusters of spherulites (Squire \& McPhie 2007).

\section{Coarsely porphyritic intrusions}

The coarsely porphyritic intrusions include basalt and basaltic andesite, hornblende-phyric basaltic andesite and dacite. Basaltic intrusions of the Eagle Hawk Basalt (Figure 3) are among the least-evolved rocks in the Cadia-Neville region and comprise abundant clinopyroxene, subordinate or no plagioclase, and rare altered olivine phenocrysts. The remaining coarsely porphyritic basaltic intrusions, including the Sundew Basalt and Gooleys Basalt, are distinguished from the Eagle Hawk Basalt by their lower clinopyroxene and higher plagioclase phenocryst abundances. Plagioclase + quartz + hornblende + apatite-phyric dacitic shallow intrusions (herein referred to as Copper Hill-type dacite: Figure 3) are the most evolved of the coarsely porphyritic intrusions. All coarsely porphyritic intrusions have a fine- to medium-grained, holocrystalline altered groundmass, and plagioclase phenocrysts commonly display prominent alkali-feldspar rims. These units are best distinguished from the Nullawonga Latite Member by their contact relationships with adjacent volcano-sedimentary facies (Squire \& McPhie 2007), and the generally larger phenocryst sizes and more coarsely crystalline groundmass.

\section{Equigranular holocrystalline intrusions}

The equigranular, holocrystalline intrusions include gabbro, diorite, monzodiorite, monzonite and syenite (including the Cadia, Tallwood, Errowan and Tettenhall Intrusive Complexes, and the Glen Ayre Syenite). Plagioclase + clinopyroxene $+\mathrm{FeTi}$ oxide-bearing gabbros are the least evolved equigranular intrusions and have higher abundances of clinopyroxene phenocrysts $(40-60 \%)$ than other equigranular intrusions. Diorites are distinguished from monzonites and syenites by lower abundances of K-feldspar and more abundant FeTi oxides. Alkali feldspar may form prominent rims on plagioclase phenocrysts or enclose partially resorbed plagioclase laths. K-feldspar also occurs as discrete phenocrysts, or poikilitically enclosing clinopyroxene and plagioclase phenocrysts in the monzodiorite, monzonite and syenite intrusions.

\section{GEOCHRONOLOGY}

A variety of isotopic techniques have been used in the Cadia-Neville region to determine the crystallisation age of the volcanic and intrusive rocks (e.g. igneous biotite, hornblende or zircon), the age of detrital components (e.g. hornblende and zircon) and the age of magmatic/hydrothermal alteration assemblages (e.g. sericite). The results of these are summarised in Figure 4. The ages obtained for samples from the Cadia-Neville region range between about 480 and $430 \mathrm{Ma}$. However, the maximum crystallisation age possible for the region is constrained by the $468 \pm 4 \mathrm{Ma} \mathrm{U}-\mathrm{Pb}$ detrital-zircon SHRIMP ages from the Coombing Formation (Meffre et al. 2007). This isotopic age is consistent with the interpreted early Darriwilian age of the Coombing Formation based on regional stratigraphic correlations and biostratigraphic controls (Percival \& Glen 2007; Squire \& McPhie 2007). The three ${ }^{40} \mathrm{Ar} /{ }^{39} \mathrm{Ar}$ igneous hornblende ages for the monzodiorites near Junction Reefs (Perkins et al. 1992) (Figure 4) are significantly older than the Eastonian (Packham et al. 1999) calcareous sandstones of the Forest Reefs Volcanics, which they intrude, and are therefore considered here to be meaningless.

Figure 4 Time-space chart displaying isotopic age data from igneous, detrital and hydrothermal assemblages in the CadiaNeville region. For comparison, igneous, detrital and hydrothermal ages from selected units elsewhere in the Molong and Junee-Narromine Volcanic Belts, the Narromine Complex and nearby Early Silurian plutonic and volcanic rocks are also provided. Absolute ages for the Ordovician and Silurian time-scales are from Cooper (1999). Numbers in superscript at the end of the text are for age determinations from: 1, Meffre et al. (2007); 2, Pogson \& Watkins (1998); 3, Perkins et al. (1992); 4, Gray et al. (1995); 5, L. P. Black (pers. comm. 1994); 6, sample CE556; 7, sample MB482; 8, Scott (1978); 9, Crawford et al. (2007); 10, Butera et al. (2001); 11, Crawford et al. (2007); 12, Perkins et al. (1990); 13, Perkins et al. (1995); 14, Kovacs (2000); 15, Lennox et al. (2005). U-Pb in zircon SHRIMP ages reported by Perkins et al. (1992), L. P. Black (pers. comm. 1994) and Pogson \& Watkins (1998) have been increased by $1.15 \%$ because SHRIMP standard SL13 was used, which is believed to have understated the reported age by $1-1.3 \%$ (Cooper 1999). 


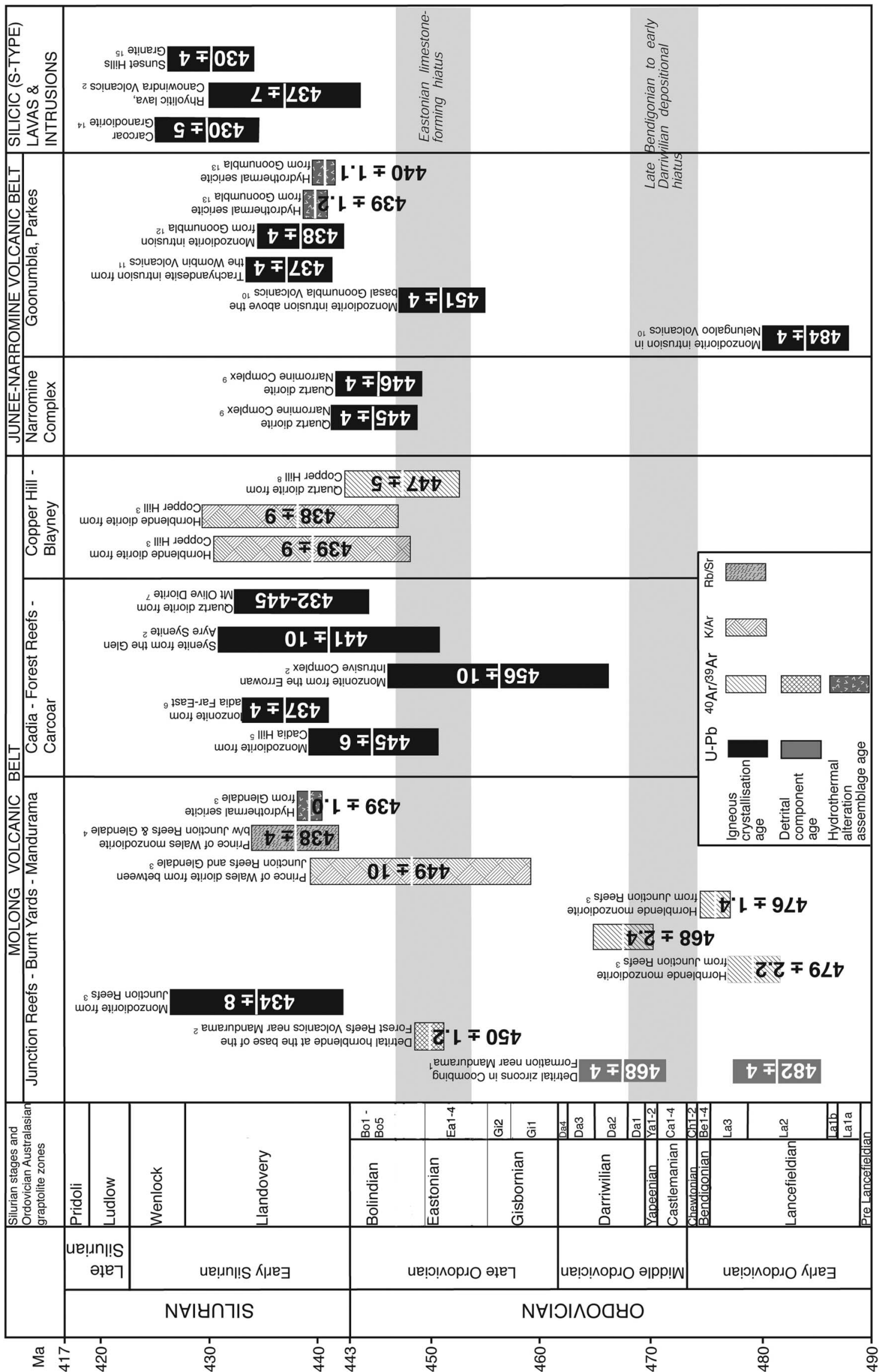


The minimum age of magmatism in the Cadia-Neville region may be constrained by the age of silicic (S-type) igneous units in the region that Collins and Hobbs (2001) correlated with the second stage of the Benambran Orogeny at $c a 430-426 \mathrm{Ma}$. The late Early Silurian age is supported by the Canowindra Volcanics (located about $10 \mathrm{~km}$ northeast of Cowra) that contain early to middle Wenlockian (ca 428-425 Ma) microfossils (Lawrie et al. 1998) and rhyolitic lavas with a U-Pb SHRIMP age of $437 \pm 7 \mathrm{Ma}$ (Pogson \& Watkins 1998). Also, the Carcoar Granodiorite near the Browns Creek mine and the Sunset Hills Granite farther south have U-Pb SHRIMP zircon ages of $430 \pm 5 \mathrm{Ma}$ (Kovacs 2000) and $430 \pm 4 \mathrm{Ma}$ (Lennox et al. 2005), respectively. Therefore, the calc-alkaline and shoshonitic magmatism in the Cadia-Neville region occurred between about 468 and $430 \mathrm{Ma}$.

The age of the main magmatic and hydrothermal event in the Cadia-Neville region is interpreted to be about $439 \mathrm{Ma}$. This is supported by isotopic data from near Junction Reefs that include a $439.3 \pm 1.0 \mathrm{Ma}$ ${ }^{40} \mathrm{Ar} /{ }^{39} \mathrm{Ar}$ age for hydrothermal sericite (Gray et al. 1995), a $438 \pm 4 \mathrm{Ma} \mathrm{Rb} / \mathrm{Sr}$ age for biotite from a monzodiorite (D. Wyborn pers. comm. in Gray et al. 1995), a $449 \pm 10 \mathrm{Ma} \mathrm{K} / \mathrm{Ar}$ age for biotite from a diorite (Prince of Wales Diorite: Perkins et al. 1992) and a $434 \pm 8 \mathrm{Ma} \mathrm{U}-\mathrm{Pb}$ SHRIMP age for magmatic zircons from a monzodiorite (Perkins et al. 1992). Also, U-Pb SHRIMP magmatic zircon ages for the Glen Ayre Syenite $(441 \pm 10 \mathrm{Ma}$ : Pogson \& Watkins 1998) and Cadia Intrusive Complex (445 \pm 6 Ma: L. P. Black pers. comm. 1994; $456 \pm 10$ Ma: Perkins et al. 1992) near Cadia, and $438 \pm 9$ and $439 \pm 8 \mathrm{Ma} \mathrm{K} / \mathrm{Ar}$ ages for igneous hornblende from intrusions at Copper Hill (Perkins et al. 1992). The ca $439 \mathrm{Ma}$ age for magmatism and alteration near Cadia is similar to that recorded at Goonumbla, near Parkes in the Junee-Narromine Volcanic Belt, where other ages include a $438 \pm 3.6 \mathrm{Ma} \mathrm{U}-\mathrm{Pb}$ SHRIMP zircon age for a monzodiorite (Perkins et al. 1990) and $439.2 \pm 1.2 \mathrm{Ma}$ (Perkins et al. 1990) and $440 \pm 1.1 \mathrm{Ma}$ (Perkins et al. 1995) ${ }^{40} \mathrm{Ar} /{ }^{39} \mathrm{Ar}$ ages for hydrothermal sericites.

However, most of the intrusions in the Cadia-Neville region are hosted by volcanic successions overlying the Eastonian ( $c a$ 455-450 Ma) calcareous sandstone. Thus, ages older than about $448 \mathrm{Ma}$ are problematic and represent either an inherited age or ages beyond the limits of analytical uncertainties. The $450.0 \pm 1.2 \mathrm{Ma}$ ${ }^{40} \mathrm{Ar} /{ }^{39} \mathrm{Ar}$ age on detrital hornblende from the base of the Forest Reefs Volcanics (Pogson \& Watkins 1998) is at least 4 million years younger than the late Darriwilian to late Gisbornian graptolite assemblage from the overlying black mudstone facies (Squire \& McPhie 2007), and thus is also problematic. Butera et al. (2001) recorded an age on monzodiorite at Goonumbla (Junee-Narromine Volcanic Belt) of $451 \pm 4 \mathrm{Ma}$, suggesting that an earlier magmatic event occurred around $450 \mathrm{Ma}$ : the significance of this is discussed below.

The coarsely porphyritic and equigranular holocrystalline intrusions dated by radiogenic isotope techniques in the Cadia-Neville-Carcoar region (Figure 4) have shoshonitic geochemical affinities. However, the intrusions dated by Perkins et al. (1992) from the Junction Reefs - Burnt Yards-Mandurama region have high-K calc-alkaline affinities (P. Blevin pers. comm.
2004). Although the compositions of the rocks analysed by Gray et al. (1995) from Junction Reefs are unknown, they are inferred to be high-K calc-alkaline based on nearby geochemical data presented here and by Wyborn and Henderson (1996).

\section{$\mathrm{U}-\mathrm{Pb}$ SHRIMP results}

Four samples from igneous rocks in the Cadia-Neville region were submitted for $\mathrm{U}-\mathrm{Pb}$ in zircon SHRIMP dating. These included: (i) a highly porphyritic trachyandesite from the Nullawonga Latite Member (sample 147721); (ii) a hornblende-phyric high-K calcalkaline basaltic andesite (sample PBD144: Duerden 1999); (iii) a quartz + hornblende + plagioclase-phyric diorite from the Mt Olive Diorite (MB482); and (iv) a monzonite from the Cadia Intrusive Complex (CE556). Unfortunately, no zircons suitable for $\mathrm{U}-\mathrm{Pb}$ age dating were found in the hornblende-phyric basaltic andesite, and the few zircons from the Nullawonga Latite Member trachyandesite yielded ages that were considered to be geologically insignificant and are therefore disregarded.

\section{MT OLIVE DIORITE}

Results from the analysis of nine zircons from the Mt Olive Diorite sample (MB482) are given in Figure 5 (Table 1). The Tera-Wasserburg concordia plot of total ${ }^{207} \mathrm{~Pb} /{ }^{206} \mathrm{~Pb}$ vs total calibrated ${ }^{238} \mathrm{U} /{ }^{206} \mathrm{~Pb}$ shows that seven analyses are of areas that have lost radiogenic $\mathrm{Pb}$. Only two analyses have no common $\mathrm{Pb}$, and are concordant at about $468 \mathrm{Ma}$. However, an age of about $468 \mathrm{Ma}$ is older than the late Eastonian calcareous sandstone facies that underlie the host succession to the Mt Olive Diorite (Packham et al. 1999; Squire \& McPhie 2007). Instead, the $468 \mathrm{Ma}$ age does match the dominant detrital-zircon age population of the underlying Coombing Formation ( $468 \pm 4 \mathrm{Ma}$ : Meffre et al. 2007) and thus may represent zircons inherited from underlying formations.

The small sample population, large scatter of dates and evidence for radiogenic $\mathrm{Pb}$ loss for the seven younger zircon analyses mean that no statistics were possible on the dataset. Despite this, the seven younger analyses appear to produce two groupings, one between about 460 and $448 \mathrm{Ma}$ and the other between about 445 and $432 \mathrm{Ma}$. The older age is also older than the inferred late Eastonian age of the underlying calcareous sandstone and siltstone facies, whereas the younger age overlaps with the age of similar shoshonitic intrusions elsewhere in the region. The crystallisation age is considered to range from about 445 to $432 \mathrm{Ma}$, based on the limits of analytical uncertainty for the three youngest ages determined here.

\section{CADIA INTRUSIVE COMPLEX}

Twenty zircon grains were analysed from a Cadia FarEast monzonite (CE556: Table 1). The Tera-Wasserburg concordia plot of the total ${ }^{207} \mathrm{~Pb} /{ }^{206} \mathrm{~Pb}$ vs the total calibrated ${ }^{238} \mathrm{U} /{ }^{206} \mathrm{~Pb}$ (Figure 5) shows a relatively simple grouping, although a weighted mean of the ${ }^{238} \mathrm{U} /{ }^{206} \mathrm{~Pb}$ ages has excess scatter $(\mathrm{MSWD}=3.1$ ). If the 

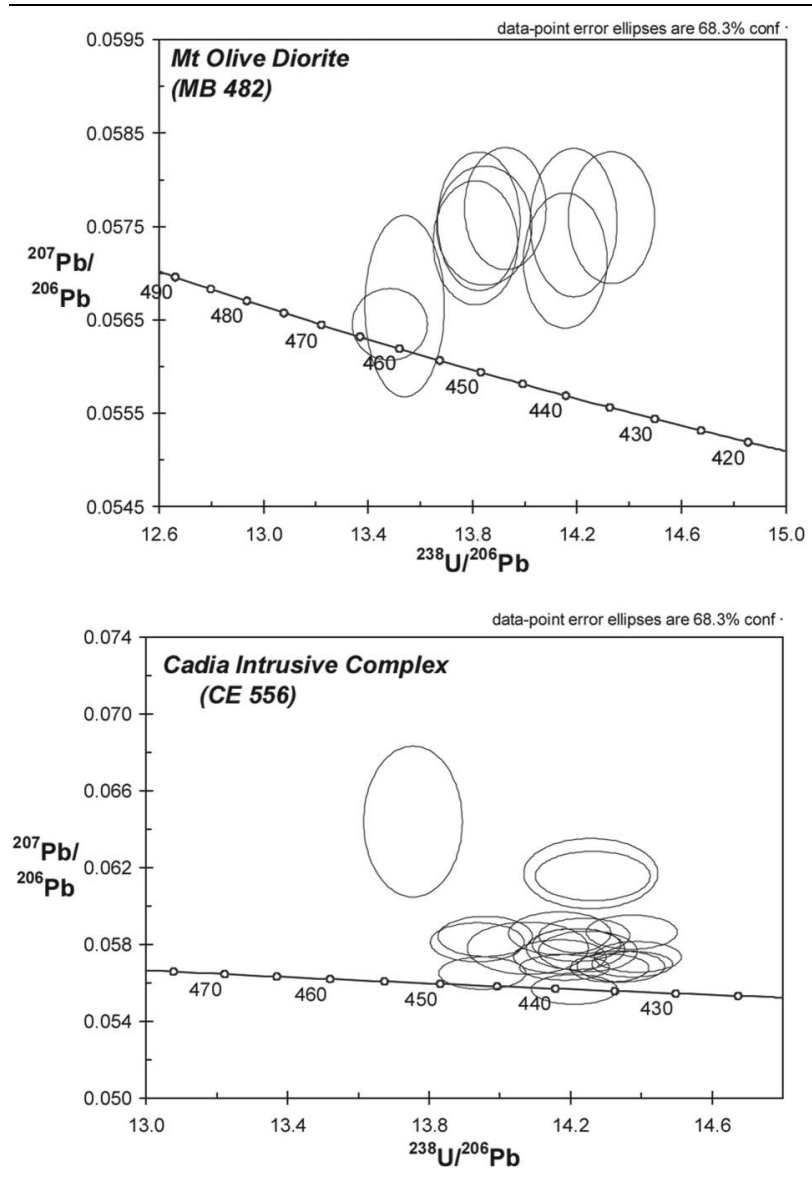

Figure 5 Tera-Wasserburg concordia plots of the total ${ }^{207} \mathrm{~Pb} /{ }^{206} \mathrm{~Pb}$ vs the total calibrated ${ }^{238} \mathrm{U} /{ }^{206} \mathrm{~Pb}$ for the zircons analysed by $\mathrm{U}-\mathrm{Pb}$ SHRIMP from the coarsely porphyritic intrusions of the Mt Olive Diorite and Cadia Intrusive Complex. Sample MB482 is a quartz dacite from the Mt Olive Diorite (Forest Reefs drillhole FRNC3, $596 \mathrm{~m}$ ), and sample CE556 is a monzonite from the Cadia Intrusive Complex (Cadia Far-East drillhole NC556, 1289 m).

four older analyses are excluded, a weighted mean of the remaining 16 analyses has no excess scatter $(\mathrm{MSWD}=0.95)$, giving a well-defined crystallisation age of $437.1 \pm 3.5 \mathrm{Ma}$. This age correlates well with the $c a$ $439 \mathrm{Ma}$ magmatic and hydrothermal event recorded elsewhere in the Macquarie Arc. The weighted mean of the four older analyses also yields a well-defined calculated age of $449 \pm 4.5 \mathrm{Ma}(\mathrm{MSWD}=0.2)$ and is interpreted to represent an inherited Eastonian zircon population.

\section{WHOLE-ROCK GEOCHEMISTRY}

This section describes the lithogeochemical characteristics of the volcanic and intrusive rocks from the Cadia-Neville region. Data for the Mt Pleasant Basalt Member and Nullawonga Latite Member are presented according to the petrographic groups outlined above. However, the coarsely porphyritic and equigranular intrusions include rocks with medium-K calc-alkaline, high-K calc-alkaline and shoshonitic affinities that generally cannot be distinguished petrographically.
Therefore, results for these intrusive rocks are presented according to their geochemical affinities. Comparisons are made with the Pliocene volcanic and intrusive rocks of the $\mathrm{Ba}$ Volcanic Group at Tavua Caldera, northern Viti Levu, Fiji. The Ba Volcanic Group is representative of the widespread and relatively well-studied intra-oceanic shoshonitic volcanism in Fiji (Whelan et al. 1985; Gill \& Whelan 1989; Rogers \& Setterfield 1994; Verbeeten 1997).

Major, trace and REE compositions of the Forest Reefs Volcanics lavas (Mt Pleasant Basalt Member and Nullawonga Latite Member) and the coarsely porphyritic and equigranular intrusions of the Cadia-Neville region are shown on variation diagrams in Figures 6-8. Key compositional features of the diverse Ordovician magmatic units of the region are used to discriminate among the different volcanic and intrusive units, and help constrain their regional correlations (see also Crawford et al. 2007).

\section{Mt Pleasant Basalt Member}

The most mafic lavas of the Mt Pleasant Basalt Member are those in the upper Mt Pleasant Basalt Member, with $52.8-55.4 \% \mathrm{SiO}_{2}, 5.5-8.0 \% \mathrm{MgO}, 0.61-0.71 \% \mathrm{TiO}_{2}, 14.4-$ $15.6 \% \mathrm{Al}_{2} \mathrm{O}_{3}$ and $2.1-4.4 \% \mathrm{~K}_{2} \mathrm{O}$ (Figure 6). The upper Mt Pleasant Basalt Member lavas are predominantly shoshonitic, with a few samples plotting in the high-K calc-alkaline field, and are classified as basaltic trachyandesites using the total alkalis $v s \mathrm{SiO}_{2}$ scheme of Le Maitre et al. (1989), although we acknowledge the uncertainty of primary $\mathrm{Na}_{2} \mathrm{O}$ contents in particular. The upper Mt Pleasant Basalt Member is relatively enriched in $\mathrm{Ni}$ (91-155 ppm) and $\mathrm{Cr}$ (265-442 ppm) compared to the basal Mt Pleasant Basalt Member (7$54 \mathrm{ppm} \mathrm{Ni}$ and 8-144 ppm $\mathrm{Cr}$ ), consistent with the presence of olivine ( \pm chromite inclusions) and abundant clinopyroxene phenocrysts in the upper unit. FeTi oxide fractionation across the differentiation interval represented by the analysed samples is indicated by decreasing $\mathrm{Fe}_{2} \mathrm{O}_{3}, \mathrm{TiO}_{2}$ and $\mathrm{V}$, with increasing $\mathrm{SiO}_{2}$. Some plagioclase accumulation is supported by its high modal abundance and the presence of weak negative $\mathrm{Eu}$ anomalies in normalised REE diagrams (Figure 8a). The increase in $\mathrm{K}_{2} \mathrm{O}$ with increasing $\mathrm{SiO}_{2}$ is reflected by the common occurrence of $\mathrm{K}$-feldspar rims on plagioclase.

The basal Mt Pleasant Basalt Member also displays shoshonitic geochemical affinities, but is more evolved than the upper Mt Pleasant Basalt Member and is classified as trachyandesite. The basal Mt Pleasant Basalt Member shows a similar fractionation trend to the upper Mt Pleasant Basalt Member (Figure 6) and is presumably related to it by fractionation of olivine, clinopyroxene, plagioclase and FeTi oxides from early magma batches that were compositionally very close to the upper Mt Pleasant Basalt Member. The change of slope in $\mathrm{P}_{2} \mathrm{O}_{5}$ at $\sim 55 \% \mathrm{SiO}_{2}$ for the basal Mt Pleasant Basalt Member reflects fractionation of apatite, and is supported by a jump in the REE pattern between Sm and $\mathrm{Nd}$ and the generally higher $(\mathrm{La} / \mathrm{Sm})_{\mathrm{N}}$ values in the evolved basal Mt Pleasant Basalt Member (2.7-3.0) than the more primitive upper Mt Pleasant Basalt Member $(2.4-2.8)$. This may be attributed to extraction of the 
Table 1 Zircon $\mathrm{U}-\mathrm{Th}-\mathrm{Pb}$ isotopic compositions for coarsely porphyritic intrusions from the Cadia-Neville region.

\begin{tabular}{|c|c|c|c|c|c|c|c|c|c|c|}
\hline \multirow{2}{*}{$\begin{array}{l}\text { Grain } \\
\text { spot }\end{array}$} & \multirow{2}{*}{$\begin{array}{c}\mathrm{U} \\
(\mathrm{ppm})\end{array}$} & \multirow{2}{*}{$\begin{array}{c}\mathrm{Th} \\
(\mathrm{ppm})\end{array}$} & \multirow[t]{2}{*}{$\mathrm{Th} / \mathrm{U}$} & \multirow[t]{2}{*}{${ }^{206} \mathrm{~Pb}^{*}(\mathrm{ppm})$} & \multirow{2}{*}{$\begin{array}{c}{ }^{204} \mathrm{~Pb} / \\
{ }^{206} \mathrm{~Pb}\end{array}$} & \multirow[t]{2}{*}{$f_{206} \%$} & \multicolumn{2}{|c|}{ Total } & \multirow{2}{*}{$\begin{array}{l}\text { Radiogenic } \\
{ }^{206} \mathrm{~Pb} /{ }^{238} \mathrm{U}\end{array}$} & \multirow{2}{*}{$\begin{array}{l}\text { Age }(\mathrm{Ma}) \pm 1 \sigma \\
{ }^{206} \mathrm{~Pb} /{ }^{238} \mathrm{U}\end{array}$} \\
\hline & & & & & & & ${ }^{238} \mathrm{U} /{ }^{206} \mathrm{~Pb}$ & ${ }^{207} \mathrm{~Pb} /{ }^{206} \mathrm{~Pb}$ & & \\
\hline \multicolumn{11}{|c|}{ MB482: Mt Olive Diorite (diorite, Forest Reefs drillhole FRNC3, $593.0 \mathrm{m:} 693483 \mathrm{mE}, 6295257 \mathrm{mN}$ ) } \\
\hline 1.1 & 1126 & 746 & 0.66 & 73 & 0.000007 & 0 & $13.254 \pm 0.115$ & $0.05638 \pm 0.00027$ & $0.07545 \pm 0.00066$ & $468.9 \pm 4.0$ \\
\hline 2.1 & 416 & 263 & 0.63 & 25.9 & 0.000041 & 0.22 & $13.787 \pm 0.124$ & $0.05770 \pm 0.00046$ & $0.07237 \pm 0.00066$ & $450.4 \pm 4.0$ \\
\hline 3.1 & 381 & 385 & 1.01 & 24 & 0.000029 & 0.15 & $13.649 \pm 0.128$ & $0.05731 \pm 0.00046$ & $0.07315 \pm 0.00070$ & $455.1 \pm 4.2$ \\
\hline 4.1 & 446 & 331 & 0.74 & 28 & 0.000002 & 0.18 & $13.693 \pm 0.144$ & $0.05750 \pm 0.00045$ & $0.07290 \pm 0.00078$ & $453.6 \pm 4.7$ \\
\hline 5.1 & 353 & 262 & 0.74 & 21.2 & 0.000037 & 0.25 & $14.276 \pm 0.130$ & $0.05760 \pm 0.00049$ & $0.06987 \pm 0.00064$ & $435.4 \pm 3.9$ \\
\hline 6.1 & 339 & 198 & 0.58 & 20.7 & - & 0.17 & $14.063 \pm 0.129$ & $0.05711 \pm 0.00051$ & $0.07099 \pm 0.00066$ & $442.1 \pm 4.0$ \\
\hline 7.1 & 425 & 350 & 0.82 & 27.4 & 0.000102 & 0.03 & $13.324 \pm 0.119$ & $0.05659 \pm 0.00068$ & $0.07503 \pm 0.00068$ & $466.4 \pm 4.1$ \\
\hline 8.1 & 271 & 239 & 0.88 & 16.5 & 0.000155 & 0.23 & $14.104 \pm 0.131$ & $0.05754 \pm 0.00056$ & $0.07074 \pm 0.00067$ & $440.6 \pm 4.0$ \\
\hline 9.1 & 315 & 219 & 0.7 & 19.8 & - & 0.19 & $13.667 \pm 0.126$ & $0.05755 \pm 0.00052$ & $0.07303 \pm 0.00068$ & $454.4 \pm 4.1$ \\
\hline \multicolumn{11}{|c|}{ CE556: Cadia Intrusive Complex (monzonite, Cadia Far-East drillhole NC556, $1289.0 \mathrm{~m}: 687373 \mathrm{mE}, 6295326 \mathrm{mN}$ ) } \\
\hline 1.1 & 142 & 51 & 0.36 & 8.6 & 0.000273 & 0.33 & $14.111 \pm 0.113$ & $0.0583 \pm 0.0008$ & $0.0706 \pm 0.0005$ & $440.0 \pm 3.5$ \\
\hline 2.1 & 471 & 193 & 0.41 & 28.3 & - & 0.11 & $14.276 \pm 0.087$ & $0.0564 \pm 0.0005$ & $0.0700 \pm 0.0003$ & $436.0 \pm 2.7$ \\
\hline 3.1 & 205 & 70 & 0.34 & 13 & 0.000702 & 1.03 & $13.622 \pm 0.108$ & $0.0643 \pm 0.0027$ & $0.0727 \pm 0.0005$ & $452.1 \pm 3.6$ \\
\hline 4.1 & 252 & 102 & 0.4 & 15.4 & 0.000089 & 0.17 & $14.111 \pm 0.103$ & $0.0571 \pm 0.0006$ & $0.0707 \pm 0.0004$ & $440.6 \pm 3.2$ \\
\hline 5.1 & 219 & 80 & 0.36 & 13.3 & 0.000109 & 0.32 & $14.193 \pm 0.101$ & $0.0582 \pm 0.0006$ & $0.0702 \pm 0.0004$ & $437.6 \pm 3.1$ \\
\hline 6.1 & 308 & 96 & 0.31 & 18.4 & 0.000029 & 0.19 & $14.370 \pm 0.096$ & $0.0571 \pm 0.0005$ & $0.0695 \pm 0.0003$ & $432.9 \pm 2.9$ \\
\hline 7.1 & 296 & 125 & 0.42 & 17.7 & 0.000126 & 0.12 & $14.315 \pm 0.096$ & $0.0565 \pm 0.0005$ & $0.0698 \pm 0.0003$ & $434.8 \pm 2.9$ \\
\hline 8.1 & 303 & 203 & 0.67 & 18.4 & 0.000062 & $<0.01$ & $14.159 \pm 0.094$ & $0.0553 \pm 0.0005$ & $0.0707 \pm 0.0003$ & $440.1 \pm 2.9$ \\
\hline 9.1 & 109 & 36 & 0.33 & 6.7 & - & 0.22 & $14.004 \pm 0.134$ & $0.0575 \pm 0.0009$ & $0.0713 \pm 0.0006$ & $443.7 \pm 4.2$ \\
\hline 10.1 & 166 & 66 & 0.4 & 10 & 0.000173 & 0.23 & $14.165 \pm 0.109$ & $0.0575 \pm 0.0007$ & $0.0704 \pm 0.0004$ & $438.8 \pm 3.4$ \\
\hline 11.1 & 183 & 58 & 0.32 & 11.4 & 0.000077 & 0.24 & $13.836 \pm 0.104$ & $0.0578 \pm 0.0007$ & $0.0721 \pm 0.0004$ & $448.8 \pm 3.4$ \\
\hline 12.1 & 182 & 59 & 0.32 & 11 & 0.000289 & 0.21 & $14.204 \pm 0.109$ & $0.0574 \pm 0.0007$ & $0.0703 \pm 0.0004$ & $437.7 \pm 3.4$ \\
\hline 13.1 & 169 & 79 & 0.47 & 10.4 & 0.000242 & 0.28 & $13.863 \pm 0.105$ & $0.0582 \pm 0.0007$ & $0.0719 \pm 0.0004$ & $447.8 \pm 3.4$ \\
\hline 14.1 & 152 & 82 & 0.54 & 9.2 & 0.000405 & 0.74 & $14.215 \pm 0.148$ & $0.0615 \pm 0.0013$ & $0.0698 \pm 0.0007$ & $435.1 \pm 4.5$ \\
\hline 15.1 & 118 & 56 & 0.48 & 7.2 & 0.000303 & 0.72 & $14.221 \pm 0.127$ & $0.0614 \pm 0.0009$ & $0.0698 \pm 0.0005$ & $435.0 \pm 3.9$ \\
\hline 16.1 & 259 & 124 & 0.48 & 16.1 & 0.000161 & 0.03 & $13.852 \pm 0.096$ & $0.0562 \pm 0.0006$ & $0.0722 \pm 0.0004$ & $449.2 \pm 3.1$ \\
\hline 17.1 & 260 & 146 & 0.56 & 15.7 & 0.000128 & 0.25 & $14.167 \pm 0.097$ & $0.0577 \pm 0.0006$ & $0.0704 \pm 0.0003$ & $438.6 \pm 3.0$ \\
\hline 18.1 & 393 & 298 & 0.76 & 23.9 & 0.000009 & 0.1 & $14.127 \pm 0.099$ & $0.0565 \pm 0.0005$ & $0.0707 \pm 0.0004$ & $440.5 \pm 3.1$ \\
\hline 19.1 & 431 & 396 & 0.92 & 25.8 & 0.000036 & 0.14 & $14.352 \pm 0.089$ & $0.0566 \pm 0.0005$ & $0.0696 \pm 0.0003$ & $433.6 \pm 2.7$ \\
\hline 20.1 & 234 & 145 & 0.62 & 14 & 0.000054 & 0.35 & $14.351 \pm 0.101$ & $0.0584 \pm 0.0006$ & $0.0694 \pm 0.0004$ & $432.8 \pm 3.0$ \\
\hline
\end{tabular}

middle REE (Sm, Eu, Gd) at a greater rate than the other light and heavy REE during apatite fractionation in the more evolved lavas (i.e. $>55 \% \mathrm{SiO}_{2}$ ) (Watson \& Green 1981).

\section{Nullawonga Latite Member}

The sparsely porphyritic and highly porphyritic Nullawonga Latite Member samples (Figure 3) display shoshonitic geochemical affinities, have 55.6-61.4\% $\mathrm{SiO}_{2}, \quad 1.0-3.6 \% \quad \mathrm{MgO}, \quad 0.28-0.62 \% \quad \mathrm{TiO}_{2}, \quad 16.6-19.1 \%$ $\mathrm{Al}_{2} \mathrm{O}_{3}$ and $3.9-8.1 \% \mathrm{~K}_{2} \mathrm{O}$ (Figure 6), and are classified as trachyandesite and trachydacite. Based on total alkalis vs $\mathrm{SiO}_{2}$ relationships, this unit is classified as latitic. The sparsely porphyritic and highly porphyritic parts of the Nullawonga Latite Member overlap in composition and show similar fractionation trends; however, the sparsely porphyritic Nullawonga Latite Member may be distinguished by slightly stronger enrichment in $\mathrm{TiO}_{2}$ and $\mathrm{P}_{2} \mathrm{O}_{5}$ and slightly lower abundance of $\mathrm{Zr}$ at similar levels of $\mathrm{SiO}_{2}$.

The sparsely and highly porphyritic parts of the Nullawonga Latite Member have similar petrographic and geochemical characteristics to the basal Mt Pleasant Basalt Member. The strong decrease in Sr at $>55 \%$ $\mathrm{SiO}_{2}$ in the Nullawonga Latite Member is coincident with the negative slope in $\mathrm{P}_{2} \mathrm{O}_{5}$, and thus may reflect apatite fractionation. Crystallisation of K-feldspar, biotite and hornblende was relatively minor, as indicated by their modal abundances and non-suppression of $\mathrm{K}_{2} \mathrm{O}$ enrichment with advancing fractionation. In addition, the separation of minor amounts of biotite in the Nullawonga Latite Member is supported by the stronger enrichment of $\mathrm{Nb}$ and LREE than of the K-group elements of similar incompatibility (Figures 6, 8b).

\section{Coarsely porphyritic and equigranular holocrystalline intrusions}

The coarsely porphyritic and equigranular holocrystalline intrusions are divided into three broad suites based on their geochemical characteristics: (i) medium-K calcalkaline; (ii) high-K calc-alkaline; and (iii) shoshonitic. The Copper Hill-type dacites are the sole representative of the medium-K calc-alkaline suite. The high-K calcalkaline suite includes the Burnt Yards Basalt (Wyborn \& Henderson 1996), hornblende-phyric basaltic andesite dykes, and gabbroic to monzonitic intrusions that include the equigranular rocks referred to by Wyborn and Henderson (1996) as Tettenhall Monzonite. The shoshonitic suite includes the Eagle Hawk Basalt (Wyborn \& Henderson 1996), Cadia Intrusive Complex 

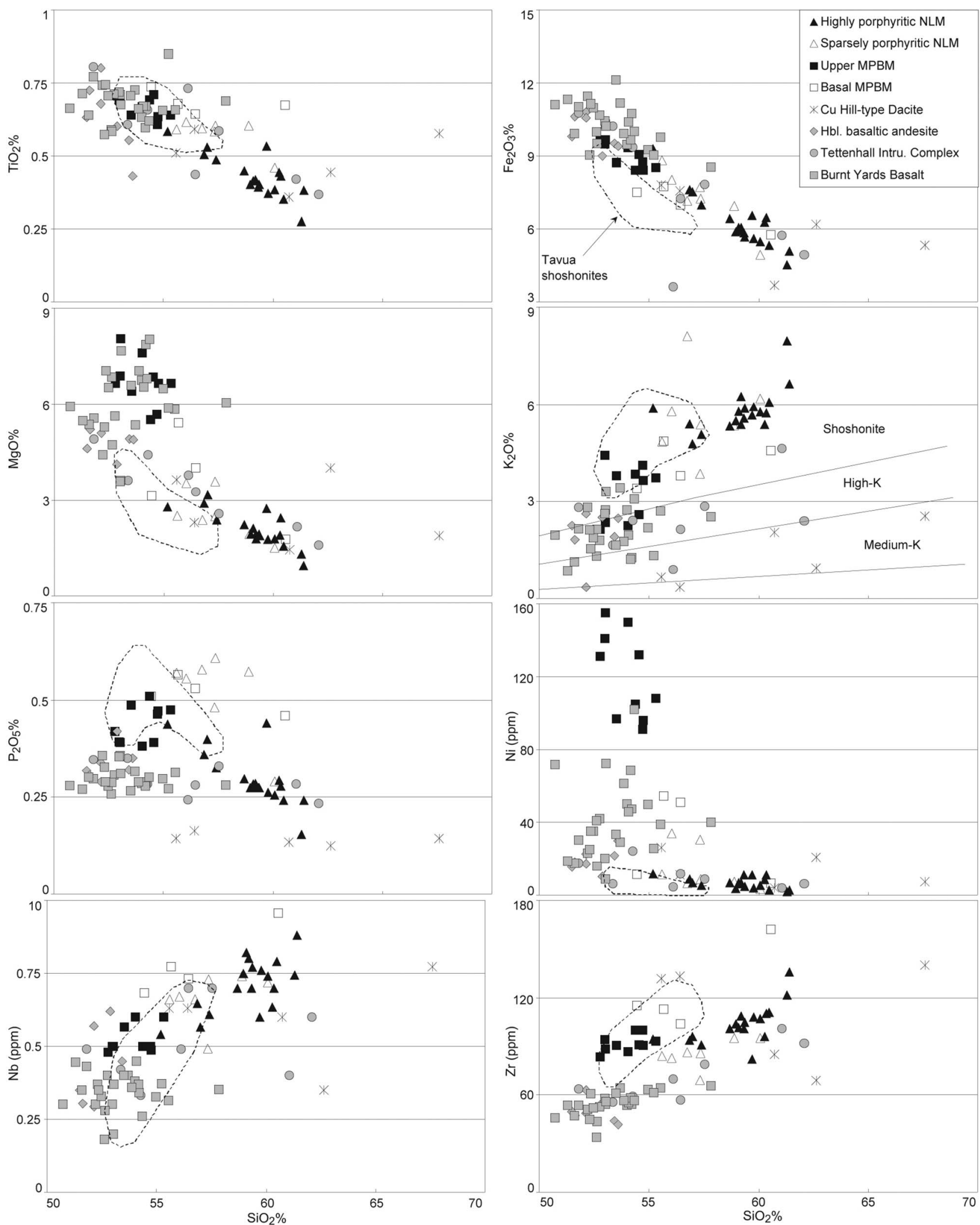

Figure 6 Selected covariation plots for the Mt Pleasant Basalt Member (MPBM), Nullawonga Latite Member (NLM), Copper $(\mathrm{Cu})$ Hill-type dacite, hornblende basaltic andesite, Burnt Yards Basalt and Tettenhall Intrusive Complex from the CadiaNeville region. Fields for the Pliocene shoshonite series volcanic and intrusive rocks from the Tavua caldera, Viti Levu, Fiji (Rogers \& Setterfield 1994) are shown for comparison. Calc-alkaline and shoshonite classification fields for the $\mathrm{K}_{2} \mathrm{O}$ vs $\mathrm{SiO}_{2}$ diagram are from Le Maitre et al. (1989). 
(Blevin 2002) and seven other units that vary from the mainly coarsely porphyritic mafic intrusions of the Sundew Basalt and Gooleys Basalt, to the more evolved, predominantly equigranular intrusions of the Mt Olive Diorite, Glen Ayre Syenite, and Tallwood and Errowan Intrusive Complexes. We have found that units defined by Wyborn and Henderson (1996) as the Cadia Monzonite, Tallwood Monzonite, Errowan Monzonite and Tettenhall Monzonite range from monzogabbro through to syenite; thus, these units have been renamed the Cadia, Tallwood, Errowan and Tettenhall Intrusive Complexes.

\section{MEDIUM-K CALC-ALKALINE SUITE}

The Copper Hill Suite dacites (Figure 3) have notably lower $\mathrm{K}_{2} \mathrm{O}(0.34-2.54 \%), \mathrm{P}_{2} \mathrm{O}_{5}(0.12-0.16 \%)$, $\mathrm{V}(60-161 \mathrm{ppm})$ and $\mathrm{Rb}(7-57 \mathrm{ppm})$ contents at similar levels of $\mathrm{SiO}_{2}$ than other volcanic and intrusive rocks from the Cadia-Neville region (Figure 6). In this respect, the Copper Hill-type dacites are quite different from the high-K calc-alkaline to shoshonitic rocks elsewhere in this region. Compositionally, they closely match shallow intrusive dacites from Copper Hill and elsewhere further north in the Molong Volcanic Belt (Crawford et al. 2007), as well as those from Cargo (Simpson et al. 2007) and in the Narromine Igneous Complex (Crawford et al. 2007) at the northern end of the Junee-Narromine Volcanic Belt. The petrogenesis of this distinctive suite is discussed in more detail in Crawford et al. (2007).

\section{HIGH-K CALC-ALKALINE SUITE}

The Burnt Yards Basalt and hornblende-phyric basaltic andesite intrusions (Figure 3) are classified as basaltic andesite to basaltic trachyandesite and have $\mathrm{K}_{2} \mathrm{O}, \mathrm{P}_{2} \mathrm{O}_{5}$, $\mathrm{Rb}$ and Ce contents that are consistent with high-K calcalkaline geochemical affinities (Figure 6). Monzogabbroic to monzonitic, predominantly equigranular intrusions that have very similar $\mathrm{K}_{2} \mathrm{O}, \mathrm{P}_{2} \mathrm{O}_{5}, \mathrm{Rb}$ and $\mathrm{Ce}$ contents to the Burnt Yards Basalt and hornblendephyric basaltic andesite intrusions (Figure 6) are common in the Tettenhall Intrusive Complex. The Burnt Yards Basalt, hornblende-phyric basaltic andesite and Tettenhall Intrusive Complex rocks display similar relatively flat REE patterns $\left[(\mathrm{La} / \mathrm{Yb})_{\mathrm{N}}=3.7-4.3,2.6-4.0\right.$ and 4.0, respectively] compared to the steeper pattern shown by the shoshonitic igneous units $\left[(\mathrm{La} / \mathrm{Yb})_{\mathrm{N}}=4-\right.$ 12: Figure 8c].

\section{SHOSHONITIC SUITE}

The Eagle Hawk, Sundew and Gooleys Basalts, Mt Olive Diorite and Glen Ayre Syenite, and Cadia, Tallwood and Errowan Intrusive Complexes (Figure 3) have higher $\mathrm{K}_{2} \mathrm{O}, \mathrm{P}_{2} \mathrm{O}_{5}, \mathrm{Rb}$ and $\mathrm{Ce}$ and lower $\mathrm{TiO}_{2}$ and $\mathrm{Zr}$ contents than the high-K calc-alkaline intrusive suites at similar levels of $\mathrm{SiO}_{2}$ (Figure 7) and steeper REE patterns [(La/ $\mathrm{Yb})_{\mathrm{N}}=4.1-11.6$ ] (Figure $8 \mathrm{~d}-\mathrm{f}$ ), and have shoshonitic affinities.

The Eagle Hawk Basalt includes some of the most primitive compositions among the analysed samples. These basalts generally have lower $\mathrm{TiO}_{2}(0.40-0.46 \%)$,
$\mathrm{Al}_{2} \mathrm{O}_{3}(10.6-14.4 \%), \mathrm{Zr}(19-28 \mathrm{ppm})$ and $\mathrm{Nb}(1-3 \mathrm{ppm})$ contents than the other intrusions at similar abundances of $\mathrm{SiO}_{2}$. In contrast, the Gooleys Basalt and Mt Olive Diorite have notably higher $\mathrm{Nb}$ contents $(7-15 \mathrm{ppm}$ and 8-21 ppm, respectively) than other intrusions in the shoshonitic suite at similar abundances of $\mathrm{SiO}_{2}$ and are among the highest $\mathrm{Nb}$ rocks in the Macquarie Arc (Crawford et al. 2007). Sundew Basalt samples are predominantly coarsely porphyritic basaltic trachyandesites petrographically similar to the Gooleys Basalt but have lower $\mathrm{Nb}$ contents (3-7 ppm). The Mt Olive Diorite displays steep REE patterns $\left[(\mathrm{La} / \mathrm{Yb})_{\mathrm{N}}=10.2\right]$ and strong LREE enrichment $\left[(\mathrm{La} / \mathrm{Sm})_{\mathrm{N}}=3.9\right]$.

The Errowan, Tallwood and Cadia Intrusive Complexes are predominantly equigranular, have dioritic to monzonitic compositions and show strikingly similar geochemical characteristics and broadly similar fractionation trends (Blevin 2002; Holliday et al. 2002). The Glen Ayre Syenite has higher $\mathrm{K}_{2} \mathrm{O}(5.6-8.0 \%)$ and $\mathrm{Rb}$ (87-136 ppm) and lower $\mathrm{TiO}_{2}(0.31-0.49 \%), \mathrm{V}(33-$ $134 \mathrm{ppm})$ and Sc (5-11 ppm) contents at similar levels of $\mathrm{SiO}_{2}$. REE patterns for the Glen Ayre Syenite are also steeper $\left[(\mathrm{La} / \mathrm{Yb})_{\mathrm{N}}=11.6\right]$ than for the Errowan, Tallwood and Cadia Intrusive Complexes $\left[(\mathrm{La} / \mathrm{Yb})_{\mathrm{N}}=4.1-10.9\right]$.

\section{NEODYMIUM ISOTOPE GEOCHEMISTRY}

The volcanic and intrusive rocks in the Cadia-Neville region have high $\varepsilon_{\mathrm{Nd}(\mathrm{i})}$ values $(+6.2$ to +7.6$)$ (Table 2$)$ that fall within the range of Ordovician igneous rocks of the Lachlan Orogen ( +5.7 to +8.0$)$ and are close to the value of the Ordovician depleted upper mantle (Wyborn and Sun 1993). The Mt Pleasant Basalt Member samples have the highest $\varepsilon_{\mathrm{Nd}(\mathrm{i})}$ values $(+7.2$ and +7.6$)$. The Copper Hilltype intrusive dacites in the Cadia-Neville region were not analysed for $\mathrm{Nd}$ isotopes for this study, but data are available for correlated intrusions elsewhere in the Molong Volcanic Belt (Crawford et al. 2007), and indicate $\varepsilon_{\mathrm{Nd}(\mathrm{i})}$ values around +6 to +7.5 . The Sundew Basalt dykes, Nullawonga Trachyandesite, Cadia, Tallwood and Errowan Intrusive Complexes and the Glen Ayre Syenite all display a restricted range in $\varepsilon_{\mathrm{Nd}(\mathrm{i})}$ values $(+6.2$ to +6.9$)$. A temporal decrease in $\varepsilon_{\mathrm{Nd}(\mathrm{i})}$ values is indicated, though $\varepsilon_{\mathrm{Nd}(\mathrm{i})}$ continued to remain relatively high.

The high $\varepsilon_{\mathrm{Nd}(\mathrm{i})}$ values, even for evolved monzodioritic compositions, indicate derivation of all the rocks analysed from isotopically primitive mantle source(s) with $\mathrm{Nd}$ isotopic signatures in the range for the depleted upper mantle at about $450 \mathrm{Ma}$, and preclude significant continental crustal involvement in magma genesis (Barron et al. 1991; Wyborn \& Sun 1993; Carr et al. 1995; Crawford et al. 2007). The Ordovician volcanic and intrusive rocks from the Cadia-Neville region were thus emplaced in an oceanic setting.

\section{MAGMATIC AFFINITIES OF THE VOLCANIC AND INTRUSIVE ROCKS}

The Late Ordovician volcanic and intrusive rocks from the Cadia-Neville region have predominantly high-K 

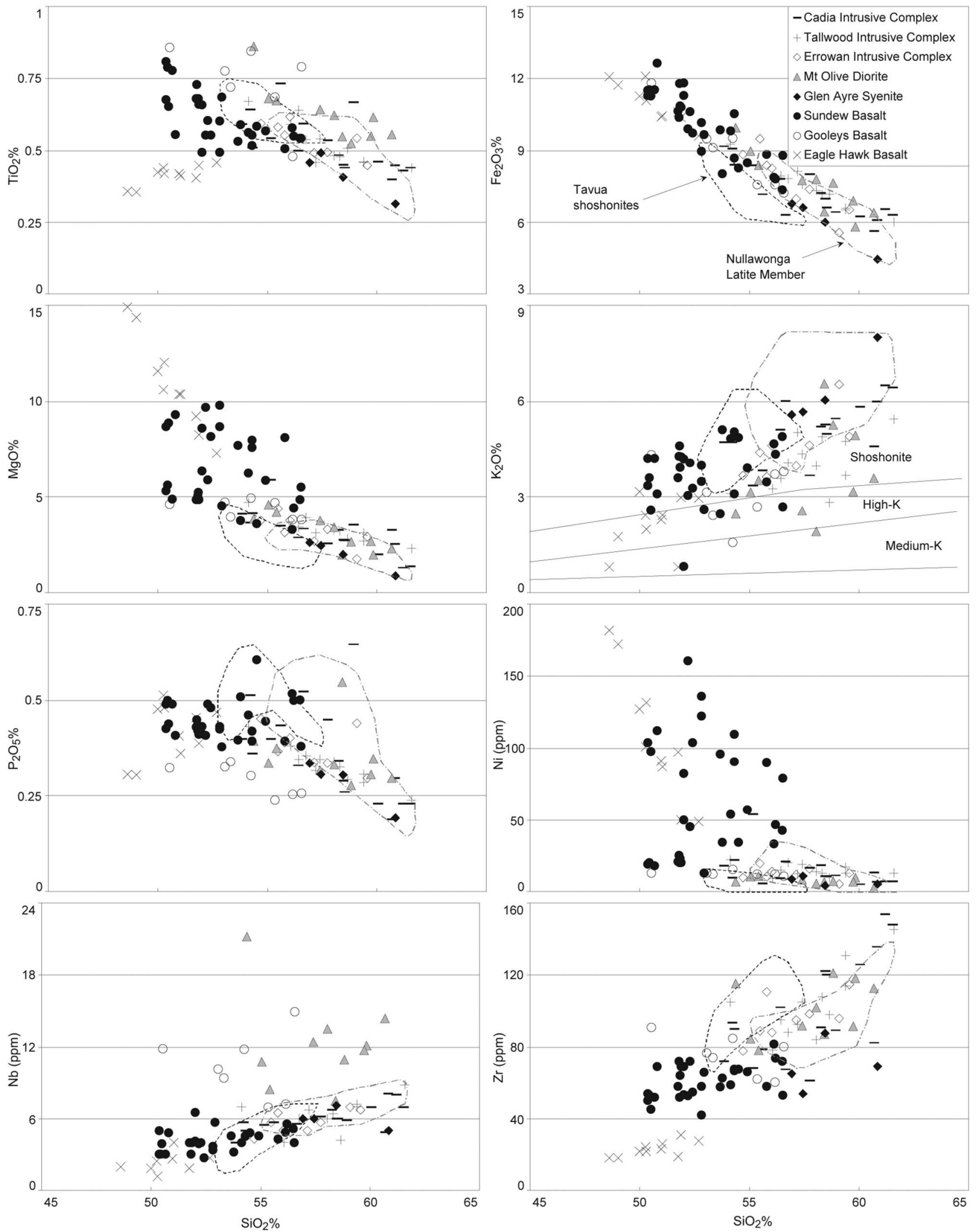

Figure 7 Selected covariation plots for the Cadia, Tallwood and Errowan Intrusive Complexes, Mt Olive Diorite, Glen Ayre Syenite, and Sundew, Gooleys and Eagle Hawk Basalt from the Cadia-Neville region. Fields for the Pliocene shoshonite series volcanic and intrusive rocks from the Tavua caldera, Viti Levu, Fiji (Rogers \& Setterfield 1994), and the Nullawonga Latite Member are shown for comparison. Calc-alkaline and shoshonite classification fields for the $\mathrm{K}_{2} \mathrm{O}$ vs $\mathrm{SiO}_{2}$ diagram are from Le Maitre et al. (1989). 

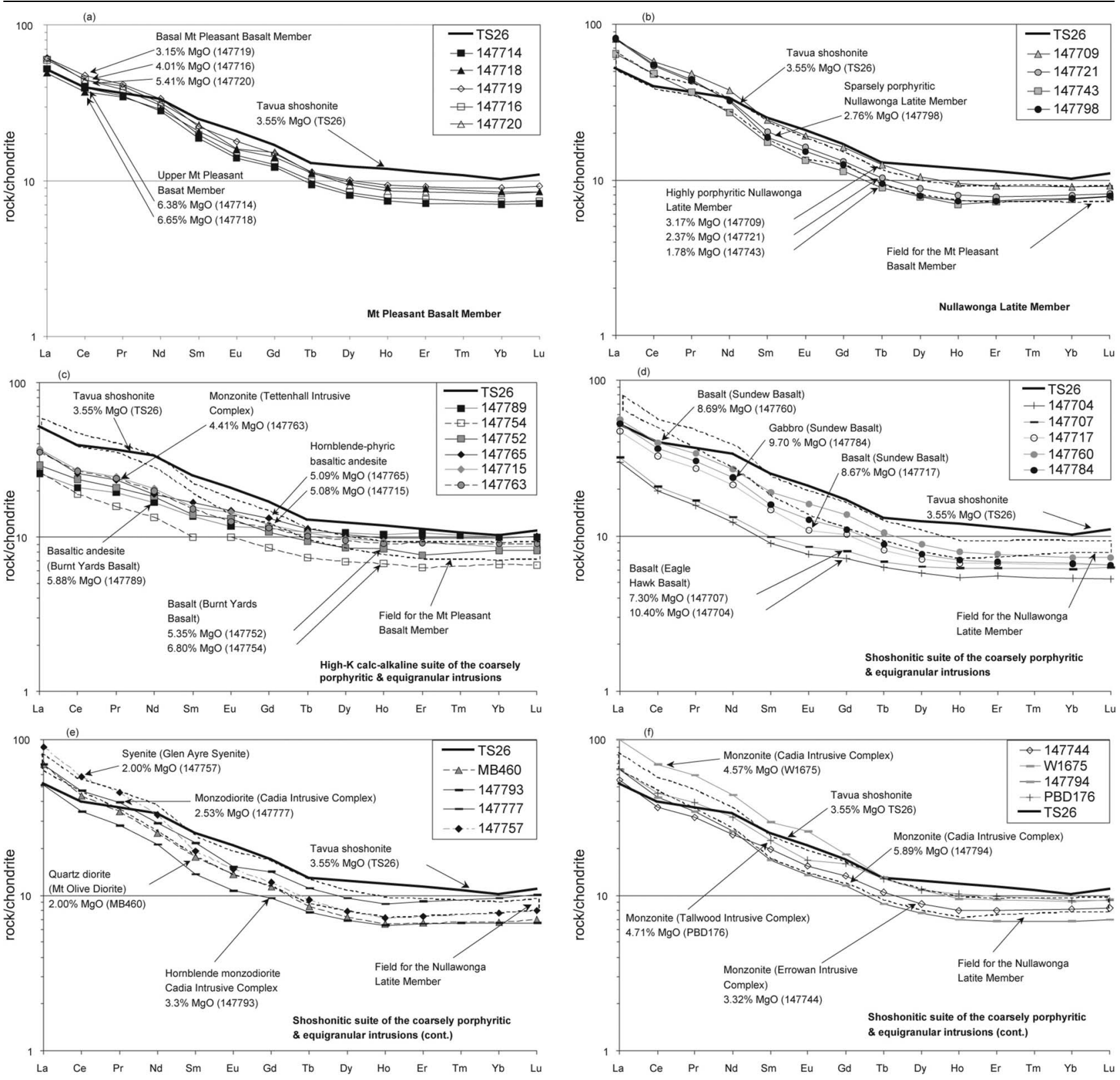

Figure 8 Chondrite-normalised REE diagram showing the REE patterns for selected volcanic and intrusive rocks from the Cadia-Neville region. For comparison, the Mt Pleasant Basalt Member field is shown in (b \& c), and the Nullawonga Latite Member field is shown in $(\mathrm{d}-\mathrm{f})$. In addition, the REE pattern for a typical Pliocene shoshonite from the Tavua Caldera, Fiji (sample TS26: Rogers \& Setterfield 1994) is shown; results were obtained only for La, Ce, Nd, Sm, Eu, Yb and Lu. Normalising data obtained from Taylor \& Gorton (1977).

calc-alkaline and shoshonitic affinities, and the Copper Hill-type dacitic intrusions are a medium-K calcalkaline suite. In contrast, the late Middle (to early Late?) Ordovician lower Blayney Basalt, Walli Volcanics and Fairbridge Volcanics have medium-K and highK calc-alkaline affinities (Figure 9) (Crawford et al. 2007). This section outlines in chronostratigraphic order the principal igneous suites of the Cadia-Neville region. More detailed correlation with similar units elsewhere in the Molong Volcanic Belt and the adjacent Ordovician volcanic belts is provided in Crawford et al. (2007).

Reliable radiogenic isotope ages are lacking for most of the Ordovician volcanic and intrusive units in the
Cadia-Neville region (Figure 4). Therefore, temporal correlations among the igneous units are reliant on the scant biostratigraphic control in the adjacent or host successions (Squire \& McPhie 2007; Percival \& Glen 2007). During the Ordovician/Silurian, temporal correlations between radiogenic isotope and biostratigraphic ages are best between the Darriwilian and Gisbornian (about 469-454 Ma) and the middle Bolindian to early Llandovery (about 447-439 Ma) (Cooper 1999). In the absence of biostratigraphic or radiogenic isotope dating control, temporal correlations may also be suggested based on geochemical similarities with igneous units of known age from elsewhere in the region. Broadly 
Table $2 \mathrm{Nd}$ isotope results from selected lithostratigraphic units in the Cadia-Neville region.

\begin{tabular}{|c|c|c|c|c|c|c|c|}
\hline Unit & Sample number & $\mathrm{Nd}(\mathrm{ppm})$ & $\mathrm{Sm}(\mathrm{ppm})$ & ${ }^{147} \mathrm{Sm} /{ }^{144} \mathrm{Nd}$ & ${ }^{143} \mathrm{Nd} /{ }^{144} \mathrm{Nd}$ & Inferred age & $\varepsilon_{\mathrm{Nd}(\mathrm{i})}$ \\
\hline Glen Ayre Syenite & 147757 & 18.39 & 3.53 & 0.1161 & 0.512745 & $\sim 440$ & +6.73 \\
\hline Tallwood Intrusive Complex & MB50 & 17.70 & 3.89 & 0.1280 & 0.512789 & $\sim 440$ & +6.54 \\
\hline Cadia Intrusive Complex & 147777 & 18.93 & 3.80 & 0.1215 & 0.512747 & $\sim 440$ & +6.46 \\
\hline Cadia Intrusive Complex & $93844535^{\mathrm{a}}$ & 18.31 & 3.72 & 0.1227 & 0.512761 & $\sim 440$ & +6.43 \\
\hline Errowan Intrusive Complex & $91844219^{a}$ & 17.26 & 3.78 & 0.1323 & 0.512814 & $\sim 440$ & +6.91 \\
\hline Sundew Basalt & 147760 & 15.50 & 3.38 & 0.1320 & 0.512762 & $\sim 440$ & +6.15 \\
\hline Sparsely porphyritic NLM & MB61 & 18.43 & 3.55 & 0.1165 & 0.512733 & $\sim 440$ & +6.47 \\
\hline Sparsely porphyritic NLM & 147798 & 17.39 & 3.35 & 0.1164 & 0.512731 & $\sim 440$ & +6.34 \\
\hline Highly porphyritic NLM & $91844169^{\mathrm{a}}$ & 19.26 & 3.77 & 0.1182 & 0.512772 & $\sim 440$ & +6.90 \\
\hline Copper Hill Dacite & $93844531^{\mathrm{a}}$ & 12.87 & 3.34 & 0.1567 & 0.512897 & $\sim 445$ & +7.13 \\
\hline Upper MPBM & $91844278^{a}$ & 18.34 & 3.87 & 0.1277 & 0.512816 & $\sim 460$ & +7.21 \\
\hline Upper MPBM & 147718 & 16.40 & 3.67 & 0.1355 & 0.512845 & $\sim 460$ & +7.57 \\
\hline
\end{tabular}

Results from a Copper Hill Dacite sample in the northern Molong Volcanic Belt are included, and are considered to be representative of the Copper Hill-type dacite. Inferred ages are based on stratigraphic relationships (Squire \& McPhie 2007) and geochronology (Figure 4). Coordinates for samples obtained as part of this study are provided with XRF results in the data repository. NLM, Nullawonga Latite Member; MPBM, Mt Pleasant Basalt Member.

${ }^{\text {a}}$ Results obtained from Wyborn \& Sun (1993).

similar temporal variations in geochemical characteristics occur throughout the Ordovician volcanic belts (Crawford et al. 2007) and enable temporal correlations to be inferred for igneous units displaying distinctive geochemical characteristics.

\section{Darriwilian to Gisbornian (ca 460-455 Ma) basaltic lavas and intrusions}

East of the Carcoar Fault, the Eagle Hawk Basalt occurs as sills and dykes up to several metres thick in the feldspathic turbidites of the Coombing Formation (Wyborn \& Henderson 1996). Petrographic similarities between the Eagle Hawk Basalt and the Blayney Volcanics were first recognised by Henderson (1991); however, Crawford et al. (2007) subdivided the Blayney Volcanics north of the Browns Creek Mine into high-K calc-alkaline lower Blayney Basalt and shoshonitic upper Blayney Basalt. The geochemical relationships among the Eagle Hawk Basalt, Mt Pleasant Basalt Member and the lower and upper Blayney Basalts are discussed below.

\section{MT PLEASANT BASALT MEMBER}

The pillowed and massive shoshonitic basalts of the Mt Pleasant Basalt Member are the oldest igneous rocks in the Cadia-Neville region and were interpreted by Wyborn and Henderson (1996) to represent the initial outpouring of basaltic lava during the development of the Forest Reefs volcanic centre. The age of the Mt Pleasant Basalt Member is unknown. However, it is underlain by feldspathic sandstones of the Coombing Formation that contain early Darriwilian detrital zircons (468 \pm 4 Ma: Meffre et al. 2007), and overlain by black mudstone with poorly preserved graptolites assigned a late Darriwilian (Da4) to late Gisbornian (Gi2) graptolites (Stevens 1954, 1957; VandenBerg \& Cooper 1992), although this is not well constrained (I. Percival pers. comm. 2006). The shoshonitic Mt Pleasant Basalt Member is compositionally very similar to the upper Blayney Basalt farther south in the Molong
Belt, and the upper Fairbridge Volcanics farther north (Crawford et al. 2007). Therefore, a Gisbornian to Eastonian age is inferred for the Mt Pleasant Basalt Member, upper Blayney Basalt and upper Fairbridge Volcanics (Figure 9).

\section{EAGLE HAWK BASALT INTRUSIONS}

Eagle Hawk Basalt sills and dykes in the Coombing Formation in the very southern part of the study area have strikingly similar $\mathrm{TiO}_{2}, \mathrm{Al}_{2} \mathrm{O}_{3}, \mathrm{Zr}$ and $\mathrm{Nb}$ contents, $\mathrm{Ti} / \mathrm{Zr}$ values, and shoshonitic geochemical affinities to the upper Blayney Basalt (Figure 10a), and may represent subvolcanic feeders to the lavas of the upper Blayney Basalt. The Eagle Hawk Basalts and upper Blayney Basalts may be distinguished from the shoshonitic Mt Pleasant Basalt Member by distinctively higher $\mathrm{Ti} / \mathrm{Zr}$ values (Figure 10a) and are clearly unrelated to $\mathrm{Mt}$ Pleasant Basalt Member magmas. The age of the Eagle Hawk Basalt is similar to the inferred Gisbornian to Eastonian age of the upper Blayney Basalt (Crawford et al. 2007).

\section{Early to middle Bolindian (450-445 Ma) medium-K calc-alkaline intrusions}

The medium-K calc-alkaline Copper Hill Suite dacite intrusions occur at the margins of the Cadia-Neville region (Figures 2,3) and have distinctive compositions that are strikingly similar to petrographically identical intrusive dacites at Copper Hill itself (Figure 10b-e), at Cargo, and in the Narromine Igneous Complex: these suites are interpreted to be derived from similar parental magmas (Crawford et al. 2007).

The Copper Hill Suite dacites near Browns Creek mine have intruded the late Eastonian Cowriga Limestone Member and thus must be younger than $452 \mathrm{Ma}$ (i.e. Ea3: Pogson \& Watkins 1998). ${ }^{40} \mathrm{Ar} /{ }^{39} \mathrm{Ar}$ age dating of the Copper Hill dacite produced an age of $447 \pm 5 \mathrm{Ma}$ (Scott 1978) (Figure 8) that correlates well with similar medium-K calc-alkaline dacites from the Narromine Complex in the Junee-Narromine Volcanic Belt 


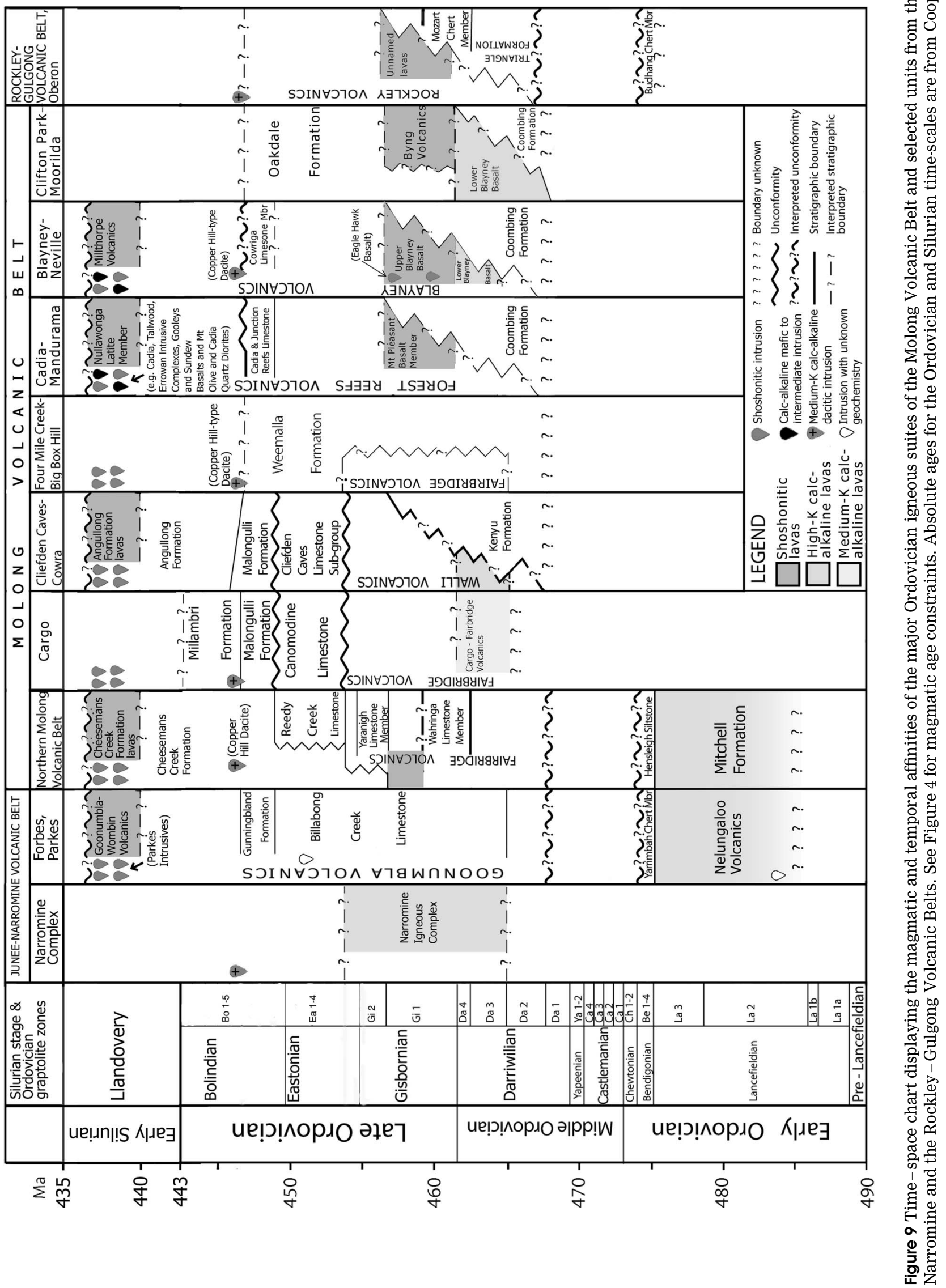



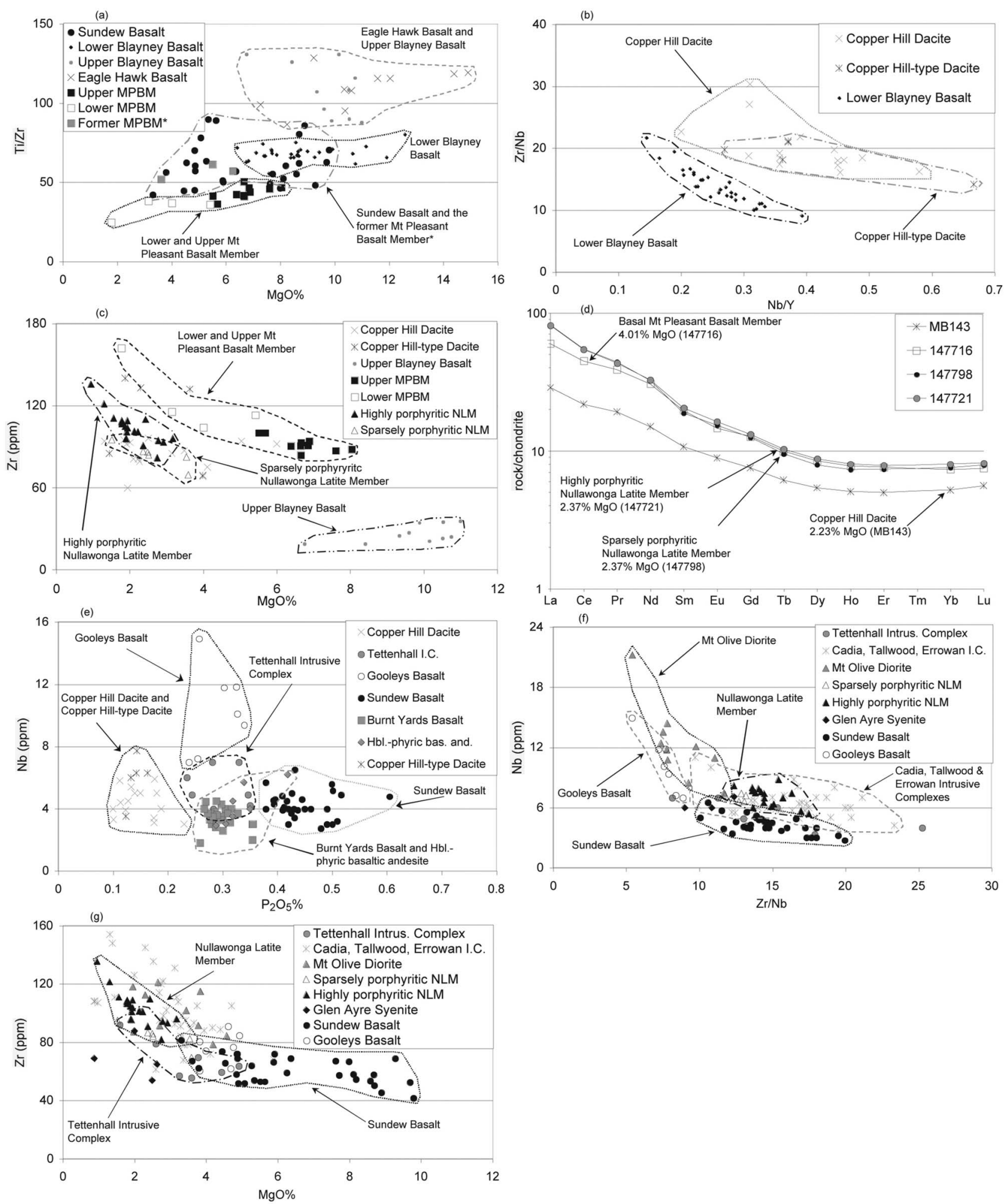

Figure 10 Covariation plots and REE patterns showing the similarities or differences between the key volcanic and intrusive units in the Cadia-Neville region. Note, the former Mt Pleasant Basalt Member (former MPBM*) in plot (a) refers to the three samples interpreted by Wyborn \& Henderson (1996) to define the north-striking extension of the Mt Pleasant Basalt Member near Carcoar (Figure 1). Data for the Copper Hill Dacite are from Crawford et al. (2007). Normalising data for the REE patterns in (d) obtained from Taylor \& Gorton (1977).

(449 $\pm 5 \mathrm{Ma}$ and $441 \pm 5.5 \mathrm{Ma}$ : Crawford et al. 2007). The age of the Copper Hill Suite medium-K calc-alkaline intrusions in the study region is therefore inferred to be about 450-445 Ma.

\section{Early Llandovery (ca $\mathbf{4 4 3} \mathrm{Ma}$ ) trachyandesites}

The Mt Pleasant Basalt Member and Nullawonga Latite Member form the major extrusive units in the Forest Reefs Volcanics. Both have shoshonitic geochemical 
affinities and display broadly similar REE patterns, although at roughly similar $\mathrm{SiO}_{2}$ and $\mathrm{MgO}$ contents the evolved Mt Pleasant Basalt Member trachyandesites have slightly higher $\mathrm{Zr}$ and $\mathrm{TiO}_{2}$ contents than the Nullawonga Latite Member (Figures 6, 10c, d). The strikingly similar compositions of the evolved Mt Pleasant Basalt Member and Nullawonga Latite Member indicate that a very similar mantle source and partial melting processes persisted over this time interval. However, biostratigraphic data (Stevens 1954, 1957; VandenBerg \& Cooper 1992) suggest that the Mt Pleasant Basalt Member was emplaced between 462 and $454 \mathrm{Ma}$, whereas stratigraphic and magmatic correlations indicate the Nullawonga Latite Member was emplaced at about $443 \mathrm{Ma}$. Therefore, the Mt Pleasant Basalt Member and Nullawonga Latite Member are separated by between 15 and 20 million years.

\section{Early Llandovery (ca $439 \mathrm{Ma}$ ) coarsely porphyritic and equigranular intrusions}

\author{
HIGH-K CALC-ALKALINE INTRUSIONS
}

A suite of high-K calc-alkaline intrusions (Burnt Yards Basalt, hornblende-phyric basaltic andesite dykes and the Tettenhall Intrusive Complex) occur in the study area (Figure 3), and despite small variations in $\mathrm{Zr}$ at any level of $\mathrm{MgO}$, these are taken to be broadly comagmatic (Figures 6, 8, 10e-g). The age of the Tettenhall Intrusive Complex indicates that these are likely to have been emplaced at about $439 \mathrm{Ma}$.

\section{SHOSHONITIC INTRUSIONS}

Wyborn and Henderson (1996) suggested that the (highly porphyritic) Nullawonga Latite Member and the holocrystalline intrusions of the Cadia, Tallwood and Errowan Intrusive Complexes, Mount Olive Diorite and Glen Ayre Syenite, were essentially comagmatic and contemporaneous. Although similar in evolved composition, the Nullawonga Latite Member and the shoshonitic holocrystalline intrusions define different $\mathrm{Zr}$ fractionation trends (Figure 10g), and therefore are not strictly comagmatic. Five $\mathrm{U}-\mathrm{Pb}$ in zircon SHRIMP ages from the shoshonitic, coarsely porphyritic intrusions in the Cadia-Neville-Carcoar region (Figure 4) have an interpreted age of about $439 \mathrm{Ma}$, clearly indicating that a second shoshonitic magmatic event occurred in the early Llandovery.

\section{PLIOCENE TECTONIC SETTING OF FIJI: A MODERN ANALOGUE}

Similarities in the major, trace and rare-earth element contents and $\varepsilon_{\mathrm{Nd}(\mathrm{i})}$ isotopic characteristics for shoshonites of the Cadia-Neville region (Wyborn 1992; Wyborn \& Sun 1993) and Pliocene Ba Volcanic Group, northern Viti Levu, Fiji (Rogers \& Setterfield 1994) (Figures 6-8), indicate that similar mantle sources and petrogenetic processes operated during the evolution of the volcanic and intrusive rocks in both regions. The Pliocene tectonic setting of Fiji may therefore represent a modern analogue for interpreting the Ordovician tectonic evolution Macquarie Arc.

At about $12-10 \mathrm{Ma}$, fragmentation of the Vitiaz Arc and opening of the North Fiji Basin occurred, forcing clockwise rotation of the New Hebrides Arc and anticlockwise rotation of the Fiji Platform (Figure 11a, b) (Falvey 1975, 1978; Kroenke 1984; Musgrave \& Firth 1999). In Fiji, disruption of the Eocene to Early Oligocene arc led to regional uplift, tilting and generation of low- to medium-K gabbros and trondhjemites of the Colo Plutonic Suite (Gill \& Stork 1979; D. Carroll pers. comm. 2002), although medium-K to high-K calc-alkaline magmatism recommenced at about $8 \mathrm{Ma}$ (Whelan et al. 1985). However, at about $5.5 \mathrm{Ma}$, arc magmatism shut down abruptly, and the arc moved into an extensional phase marked magmatically by shoshonite-dominated volcanism between about 5.5 and 3.5 Ma (Gill \& Whelan 1989; Rogers \& Setterfield 1994) (Figure 11b, c). The shoshonitic volcanism occurred mainly along three broad lineaments (Viti Levu, Lomaiviti and Vatulele-Beqa Lineaments) near the western rifted-arc margin of Fiji, farthest from the convergent Pacific Plate boundary (Figure 12) (Gill \& Whelan 1989). Subordinate high-K calc-alkaline magmas were erupted from volcanoes adjacent to the shoshonitic lavas.

The shoshonitic lavas in Fiji were erupted after subduction had ceased. The extensional tectonic regime responsible for the opening of the North Fiji and Lau Basins (Hamburger \& Isacks 1987; Hamburger et al. 1990) probably facilitated melting of sub-Fiji arc lithosphere generated during earlier subduction associated with the Vitiaz Arc system. After the cessation of subduction, lithospheric extension affected a wide region (at least $150 \mathrm{~km}$ ) and led to ascent of asthenospheric mantle. Elevation of isotherms most likely caused adjacent lithospheric mantle domains to partially melt and produce the shoshonitic magmas in Fiji. At Tavua Caldera, northern Viti Levu, epithermal Au and porphyry- $\mathrm{Cu}$ mineralisation is associated with shoshonitic intrusions (Eaton \& Setterfield 1993).

\section{INTERPRETATION OF THE TECTONIC SETTING FOR THE ORDOVICIAN VOLCANIC SUCCESSIONS}

The dominance of high-K calc-alkaline and shoshonitic compositions in the Cadia-Neville region suggests that these magmas were unlikely to have formed in a newly constructed intra-oceanic arc built on oceanic crust. Instead, the similarities in composition between these Ordovician igneous rocks and the magmas erupted during the Pliocene in Fiji suggest that the former may have been generated by pre-processed mantle above the subduction zone during an early Gisbornian and early Llandovery extensional phase of the arc, thus requiring an earlier subduction episode.

The medium-K calc-alkaline Cargo Volcanics, west of the Cadia-Neville region, are some of the most 'arc-like' volcanic rocks in the Macquarie Arc (Crawford et al. 2007) and presumably indicate the resumption of arc magmatism following the likely but poorly defined Chewtonian to early Darriwilian hiatus (cf. Namosi Andesite Formation, Fiji). The new arc is built on the previous arc (represented by the earliest Ordovician 


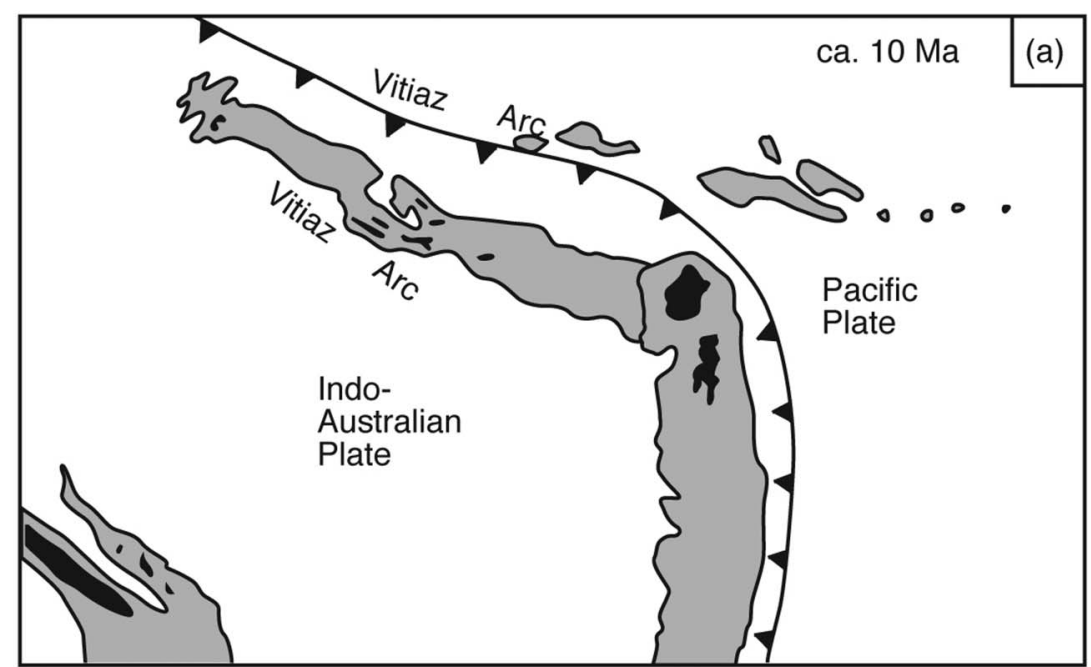

Figure 11 Tectonic reconstruction of the New Hebrides-Tonga region at (a) about $12 \mathrm{Ma}$, (b) about 5.5 Ma and (c) present. The IndoAustralian Plate is fixed. The Fiji Platform rotated about $135^{\circ}$ anticlockwise (Taylor et al. 2000), and the New Hebrides Arc rotated about $40-50^{\circ}$ clockwise (Musgrave \& Firth 1999) during opening of the North Fiji Basin. It is during this episode of rapid rotation of the Fiji Platform that shoshonitic magmatism occurred (ca 5.5-3 Ma). The Tonga Arc has rotated $\sim 20^{\circ}$ during opening of the Lau Basin (Sager et al. 1994). Ridges outlined by the $4000 \mathrm{~m}$ bathymetric contour. NHT, New Hebrides Trench; TT, Tonga Trench; HFZ, Hunter Fracture Zone. Arrows indicate direction and relative magnitude of arc migration. Modified from Hathway (1993), Taylor et al. 2000 and Schellart et al. (2002).

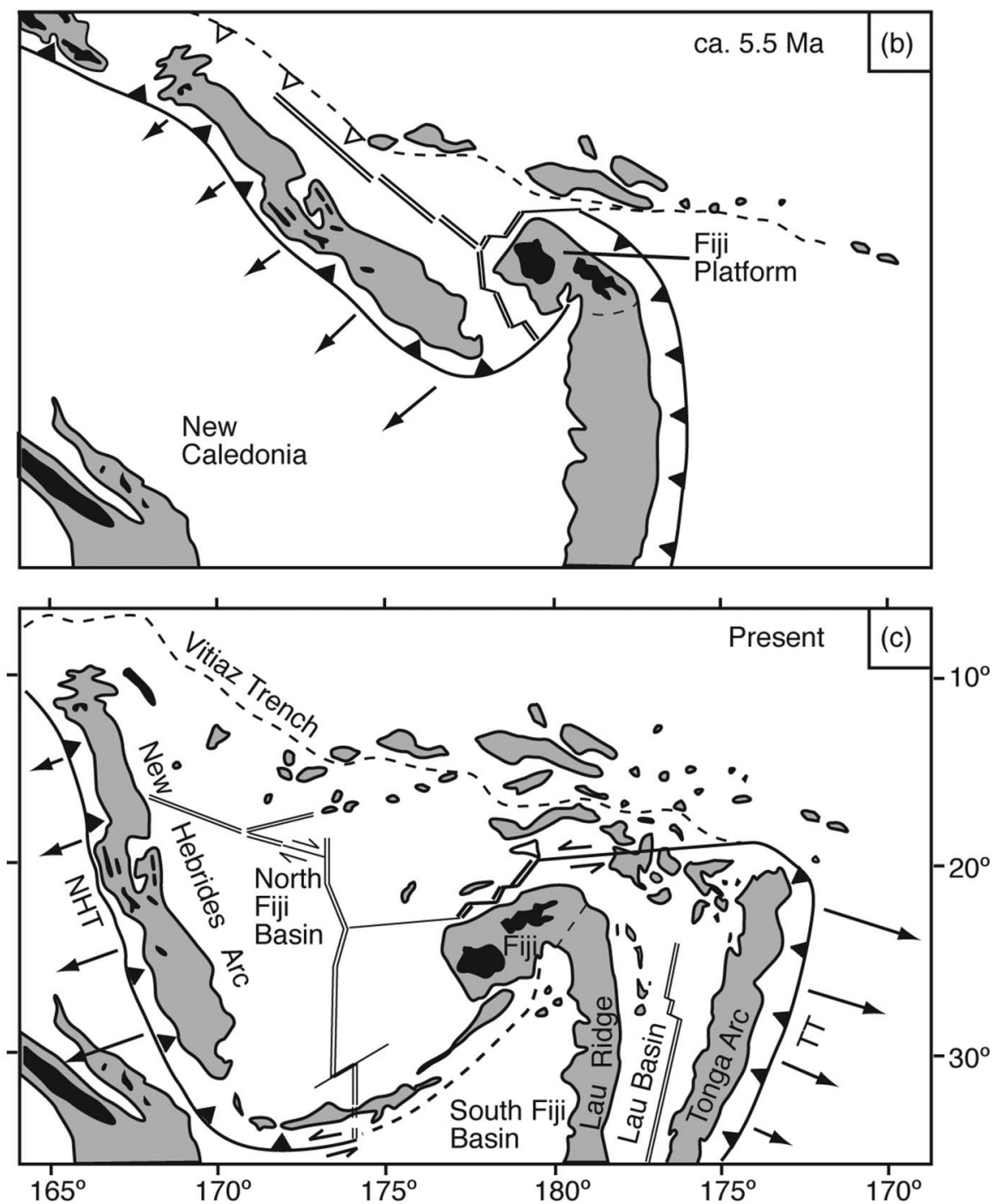

Mitchell Formation in northern Molong Volcanic Belt: Percival \& Glen 2007) and its underlying basement. Contemporaneous with, or slightly younger than, the Cargo Volcanics are high-K calc-alkaline basalts (e.g. lower Blayney Basalt). At about the start of the Gisbornian, shoshonitic basalts were erupted (e.g. Mt Pleasant Basalt Member and upper Blayney Basalt).
By analogy with the Pliocene tectonic setting in Fiji, these shoshonitic magmas were generated following shut-down of arc magmatism, when the arc moved into an extensional phase that was marked magmatically by fault-controlled linear belts of distinctive shoshonitic magmatism. Extension probably occurred due to rollback of the subducting backarc crust or, if 


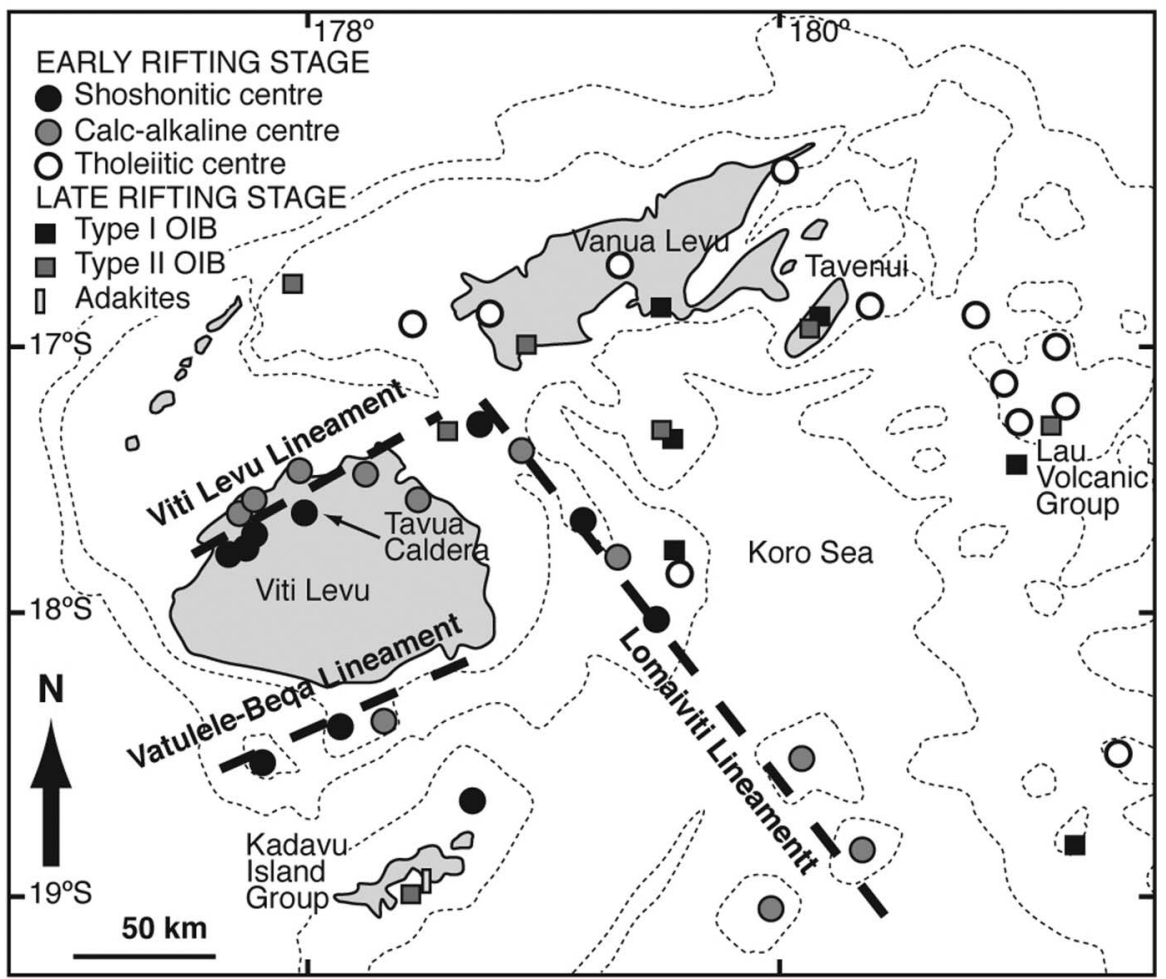

Figure 12 Sites of volcanism during the early rifting ( $c a 5.5-3.5 \mathrm{Ma}$ ) and late rifting ( $\mathrm{ca} 3 \mathrm{Ma}$ to present) stages, Fiji Platform (after Gill \& Whelan 1989). The dashed lines represent the three zones along which the calc-alkaline and shoshonitic volcanic and intrusive rocks were produced during the early rifting stage: Viti Levu, Vatulele-Beqa and Lomaiviti Lineaments. west-directed subduction recommenced, rollback of the main subducting oceanic plate (Crawford et al. 2007).

The almost simultaneous development of limestone throughout the Ordovician volcanic belts during the Eastonian suggests that a significant change in the tectonic setting occurred. Evidence supporting a major change in the tectonic setting at this time includes the cessation of (shoshonitic) magmatism and emplacement of the widespread but small-volume intrusions of quartz + hornblende + plagioclase-phyric dacites (e.g. Copper Hill Suite dacites) between about 450 and $445 \mathrm{Ma}$. This process may be similar, though not directly analogous, to the emplacement of the Colo Plutonics in Fiji. The reasons for the abrupt termination of the shortlived adakitic magmatism at about $445 \mathrm{Ma}$ are uncertain, but it may have been due to far-field effects outside the area encompassed by the known Ordovician Macquarie Arc rocks in New South Wales. This is discussed further in Crawford et al. (2007).

Shoshonite-dominated magmatism recurred at about $443 \mathrm{Ma}$ (e.g. Nullawonga Latite Member and associated intrusive complexes), and was notably more evolved than the pre-Eastonian shoshonites, with slightly lower $\varepsilon_{\mathrm{Nd}(\mathrm{i})}$ values and displayed evidence of inherited zircons. Late shoshonitic intrusions were probably emplaced around $439 \mathrm{Ma}$. By contrast with the Middle Ordovician shoshonitic magmas of the Mt Pleasant Basalt Member, this probably reflects slower ascent through thicker crust, resulting in more fractionated magmas and a greater opportunity for assimilation of older crustal material.

\section{SUMMARY}

The basaltic lavas of the Mt Pleasant Basalt Member may be broadly correlated with the upper Blayney
Basalt and record the earliest shoshonitic volcanism in the southern Molong Volcanic Belt in the late Darriwilian to Gisbornian (ca 463-453 Ma). Following, or possibly synchronous with, the major Eastonian hiatus (Packham et al. 1999), magmatism recommenced in the early to middle Bolindian ( $\mathrm{ca} 448-445 \mathrm{Ma}$ ) and is recorded by the widespread, though small-volume, medium-K calc-alkaline Copper Hill-type dacite that has adakitic characteristics. The Nullawonga Latite Member represents a second phase of shoshonitic volcanism ( $c a 443 \mathrm{Ma}$ ) following the Eastonian hiatus. Despite the Mt Pleasant Basalt Member being at least 15 (but possibly up to 20) million years younger than the Nullawonga Latite Member, they have a strikingly similar geochemistry indicating that a similar mantle source and partial melting processes were involved over this time interval. Shoshonitic and high-K calc-alkaline coarsely porphyritic and equigranular holocrystalline intrusions were emplaced broadly contemporaneous with the shoshonitic volcanism of the Nullawonga Latite Member. The late shoshonitic intrusions are not strictly comagmatic with the Nullawonga Latite Member, though very similar in composition, and were probably emplaced around $439 \mathrm{Ma}$.

Major, trace, rare-earth element and $\mathrm{Nd}$ isotopic characteristics of the shoshonitic rocks from the Cadia-Neville region strongly resemble the Pliocene volcanic and intrusive rocks of the Ba Volcanic Group at Tavua Caldera, Fiji (Rogers \& Setterfield 1994). By analogy with the Pliocene tectonic setting in Fiji, the shoshonitic magmas of the Lachlan Orogen were generated following shutdown of arc magmatism when the arc moved into an extensional phase that was marked magmatically by fault-controlled linear belts of distinctive shoshonitic magmatism. The arc-type signature for the high-K calc-alkaline and shoshonitic 
intrusions may be due to pre-processing of the mantle above a subduction zone prior to collision and subsequent extension/fragmentation that led to generation of the subduction-modified magmas.

\section{ACKNOWLEDGEMENTS}

This work was funded by the Australian Research Council (Strategic Partnership - Industry Research and Training) grant. We also gratefully acknowledge the support of the following sponsors: Newcrest Mining Limited, Homestake Australia, Alkane Exploration, Hargraves Resources, Goldfields Australia, Resolute Ltd, Rio Tinto and the Geological Survey of New South Wales. P. Robinson and S. Stevens from the University of Tasmania assisted with XRF and ICP-MS analyses and thin-section preparation, respectively. M. Fanning from the Research School of Earth Sciences at Australian National University is thanked for SHRIMP data, as is J. Foden from University of Adelaide for $\mathrm{Nd}$ isotope analyses. Peter Duerden's Honours thesis provided useful information towards this study. Phil Blevin and Anthony Harris are thanked for constructive and thoughtful reviews, as are Dick Price and Evan Leitch, who reviewed an earlier version of this manuscript.

\section{REFERENCES}

BARRon L. M., Suppel D. W., Slansky E., Johan Z., OHNENSTETTER M. \& SPENCER R. 1991. The Fifield platinum province (FPP). Geological Society of Australia Abstracts 29, 3.

BLEVIN P. 2002. The petrographic and compositional character of variably K-enriched magmatic suites associated with Ordovician porphyry $\mathrm{Cu}-\mathrm{Au}$ mineralisation in the Lachlan Fold Belt, Australia. Mineralium Deposita 37, 87-99.

Butera K. M., Williams I. S., Blevin P. L. \& Simpson C. J. 2001. Zircon $\mathrm{U}-\mathrm{Pb}$ dating of Early Palaeozoic monzonitic intrusives from the Goonumbla area, New South Wales. Australian Journal of Earth Sciences 48, 457-464.

CARR G. R., Dean J. A., Suppel D. W. \& Heithersay P. S. 1995. Precise lead isotope fingerprinting of hydrothermal activity associated with Ordovician to Carboniferous metallogenic events in the Lachlan Fold Belt of New South Wales. Economic Geology 90, 1467-1505.

Coluins W. J. \& HoBBS B. E. 2001. What caused the Early Silurian change from mafic to silicic (S-type) magmatism in the eastern Lachlan Fold Belt? Australian Journal of Earth Sciences 48, 25-41.

Compston W., Williams I. S., Kirschvink J. L., ZichaO Z. \& GUOGAN M. 1992. Zircon U-Pb ages for the Early Cambrian timescale. Journal of the Geological Society of London 149, 171-184.

COOPER R. A. 1999. The Ordovician time scale - calibration of graptolite and conodont zones. Acta Universitatis Carolinae: Geologica 43, 1-4.

Crawford A. J, MefFre S., SQuire R. J., BarRon L. M. \& FALLOON T. J. 2007. Middle and Late Ordovician magmatic evolution of the Macquarie Arc, Lachlan Orogen, New South Wales. Australian Journal of Earth Sciences 54, 181-214.

DUERDEN P. B. 1999. Lithostratigraphy and lithochemistry of Ordovician volcano-plutonic rocks in the Blayney area, central Molong belt, NSW. BSc (Hons) thesis, University of Tasmania, Hobart (unpubl.).

EATON P. C. \& SeTTERFIELD T. N. 1993. The relationship between epithermal and porphyry hydrothermal systems within the Tavua caldera, Fiji. Economic Geology 88, 1053-1083.

FALVEY D. A. 1975. Arc reversals, and a tectonic model for the North Fiji Basin. Australian Society of Exploration Geophysicists Bulletin 6, 47-49.
FALVEy D. A. 1978. Analysis of palaeomagnetic data from the New Hebrides. Australian Society of Exploration Geophysicists Bulletin 9, 117-123.

GILL J. B. \& StoRK A. L. 1979. Miocene low-K dacites and trondhjemites of Fiji. In: Barker F. ed., Trondhjemites, Dacites and Related Rocks. pp. 629-649. Elsevier, Amsterdam.

GILL J. B. \& WHELAN P. 1989. Early rifting of an oceanic island arc (Fiji) produced shoshonitic to tholeiitic basalts. Journal of Geophysical Research 94, 4561-4578.

GLEN R. A. 1992. Thrust, extensional and strike-slip tectonics in an evolving Palaeozoic orogen - a structural synthesis of the Lachlan Orogen of southeastern Australia. Tectonophysics 214, 341-380.

GLEN R. A., WALShe J. L., BARRON L. M. \& WATKINS J. J. 1998. Ordovician convergent-margin volcanism and tectonism in the Lachlan Sector of east Gondwana. Geology 26, 751-754.

GRAY N., MANDYCZEWSKY A. \& HINE R. 1995. Geology of the zoned gold skarn system at Junction Reefs, New South Wales. Economic Geology 90, 1533-1552.

HAMBURGER M. W., Everingham I. B., IsACKS B. L. \& BARAZANGI M. 1990. Seismicity and crustal structure of the Fiji Platform, Southwest Pacific. Journal of Geophysical Research 95, 2253-2573.

HAMBURGER M. W. \& ISACKS B. L. 1987. Deep earthquakes in the southwest Pacific: a tectonic interpretation. Journal of Geophysical Research 92, 13841-13854.

HathWAY B. 1993. The Nadi Basin: Neogene strike-slip faulting and sedimentation in a fragmented arc, western Viti Levu, Fiji, Journal of the Geological Society of London 150, 563-582.

HENDERSON G. A. M. 1991. Notes on the geology of the Blayney area. Bureau of Mineral Resources Record 1991/66.

Holliday J. R., Wilson A. J., Blevin P. L., Tedder I. J., Dunham P. D. \& PfITZner M. 2002. Porphyry gold-copper mineralisation in the Cadia District, eastern Lachlan Fold Belt, New South Wales, and its relationship to shoshonitic magmatism. Mineralium Deposita 37, 100-116.

Kovacs N. 2000. Magmatic and hydrothermal evolution of the Browns Creek Intrusive Complex and associated gold mineralisation. MSc thesis, Australian National University. Canberra (unpubl.).

KroEnke L. W. 1984. Cenozoic tectonic development of the southeast Pacific. CCOP/SOPAC Technical Bulletin 6.

Lawrie K. C., Mernagh T., Black L. P. \& Wyborn D. 1998. Au$\mathrm{Cu}$ mineralization at the Bald Hill Prospect, Lachlan Fold Belt, New South Wales. Geological Society of Australia Abstracts 49, 262.

Le Maitre R. W., Bateman P., Dudek A., Keller J., Le Bas M. J., Sabine P. A., SChMid R., SORENSEN H., StReCKeISen A. WOOLLEY A. R. \& ZANETTIN B. 1989. A Classification of Igneous Rocks and Glossary of Terms. Blackwell Scientific, Oxford.

Lennox P. G., TRzebski R., ARMSTRONG R. \& SiebeL W. 2005. Structural evolution and granite chronology of the central Molong Zone, Eastern Lachlan Fold Belt, Australia. Australian Journal of Earth Sciences 52, 79-100.

MefFre S., SCOTT R. J., GLEN R. A. \& SQUIRE R. J. 2007. Re-evaluation of contact relationships between Ordovician volcanic belts and the quartz-rich turbidites of the Lachlan Orogen. Australian Journal of Earth Sciences 54, 363-383.

Muir R. J., IRELAND T. R. WEAVER S. D. \& BRADSHaW J. D. 1996. Geochronology of Paleozoic magmatism in New Zealand and correlations with eastern Australia, Tasmania and Antarctica. Chemical Geology 127, 191-210.

Musgrave R. J. \& FirTh J. V. 1999. Magnitude and timing of New Hebrides Arc rotation; paleomagnetic evidence from Nendok Solomon Islands. Journal of Geophysical Research 104,330-340.

PACES J. B. \& MilLER J. D. 1993. Precise U-Pb ages of Duluth Complex and related mafic intrusions, northeastern Minnesota: geochronological insights to physical, petrogenetic, paleomagnetic and tectonomagmatic process associated with the $1.1 \mathrm{Ga}$ Midcontinent Rift System. Journal of Geophysical Research 98, 13997-14013.

PACKham G., Percival I. \& Bischoff G. 1999. Age constraints on strata enclosing the Cadia and Junction Reefs ore deposits of central New South Wales. Geological Survey of New South Wales Quarterly Notes 110, 1-12.

Percival I. G. \& GLEN R. A. 2007. Ordovician to earliest Silurian history of the Macquarie Arc, Lachlan Orogen, New South Wales. Australian Journal of Earth Sciences 54, 143-165.

PERKINS C., MCDOUgall I., ClaOUÉ-LONG J. \& HeITHERSAY P. S. 1990. ${ }^{40} \mathrm{Ar} /{ }^{39} \mathrm{Ar}$ and $\mathrm{U}-\mathrm{Pb}$ geochronology of the Goonumbla porphyry $\mathrm{Cu}-\mathrm{Au}$ deposits, New South Wales, Australia. Economic Geology 85, 1808-1824. 
Perkins C., McDougall I. \& Walshe J. L 1992. Timing of shoshonitic magmatism and gold mineralization, SheahanGrants and Glendale, New South Wales. Australian Journal of Earth Sciences 39, 99-110.

Perkins C., WALshe J. L. \& MorRison G. 1995. Metallogenic episodes of the Tasman Fold Belt System, eastern Australia. Economic Geology 90, 1443-1466

Pogson D. J. \& WATkins J. J. 1998. Bathurst 1:250 000 Geological Sheet SI/55-8: Explanatory Notes. Geological Survey of New South Wales, Sydney.

Raymond O. L., Pogson D. J., Wyborn D., Henderson G. A. M., KRYNEN J., MEAKIN S., MORgan E. J., ScOTT M. M., Stuart-Smith P., Wallace D., Warren A. Y. E., Watkins J. J. \& Glen R. A. 1998. Bathurst 1:250 000 Geological Sheet SI 55-8. Geological Survey of New South Wales, Sydney and Australian Geological Survey Organisation, Canberra.

RoBINSON P., TOWNSEND P., YU Z. \& MÜNKER C. 1998. Determination of scandium, yttrium and rare earth elements in rocks by high resolution inductively coupled plasma mass spectrometry. Geostandards Newsletter 23, 31-46.

Rogers N. W. \& SETterfield T. N. 1994. Potassium and incompatible-element enrichment in shoshonitic lavas from the Tavua Volcano, Fiji. Chemical Geology 118, 43-62.

SAgER W. W., MAClEOD C. J. \& ABRAHAMSEN N. 1994. Palaeomagnetic constraints on Tonga Arc tectonic rotation from sediments drilled at sites 841 and 841. Proceedings of the Ocean Drilling Program Scientific Results 135, 763-783.

Schellart W. P., Lister G. S. \& JeSSELl M. W. 2002. Analogue modeling of arc and backarc deformation in the New Hebrides arc and North Fiji Basin. Geology 30, 311-314.

ScOTT K. M. 1978. Geochemical aspects of the alteration-mineralisation at Copper Hill, New South Wales. Economic Geology 73, 966-976.

Simpson C. J., SCOTt R. J., CRAWFORD A. J. \& MEFFRE S. 2007. Volcanology, geochemistry and structure of the Ordovician Cargo Volcanics in the Cargo-Walli region, central New South Wales. Australia Journal of Earth Sciences 54, 315-352.

SMITH R. E. 1966. The geology of Mandurama-Panuara. Journal and Proceedings of the Royal Society of New South Wales 98, 239-262.

SQUIRE R. J. 2001. The volcanological and tectono-magmatic evolution of the Cadia-Neville region, Lachlan Fold Belt, NSW. PhD thesis, University of Tasmania, Hobart (unpubl.)

SQUIRE R. J. \& MCPHIE J. 2007. Complex volcanic facies architecture of the Forest Reefs Volcanics near Cadia, New South Wales, associated with prolonged arc-related volcanism. Australian Journal of Earth Sciences 54, 273-292.

STEVENS N. C. 1954. A note on the geology of Panuara and Angullong, south of Orange, N.S.W. Proceedings of the Linnean Society of New South Wales 78, 262-268.
Stevens N. C. 1957. Further notes on Ordovician formations of central New South Wales. Journal and Proceedings of the Royal Society of New South Wales 90, 44-50.

TAYlOR G. K., GASCOYNE J. \& COLLEY H. 2000. Rapid rotation of Fiji: paleomagnetic evidence and tectonic implications. Journal of Geophysical Research 105, 5771-5781.

TAYLOR S. R. \& GORTON M. P. 1977. Geochemical application of spark source mass spectrography-III. Element sensitivity, precision and accuracy. Geochimica et Cosmochimica Acta 41, 1375-1380.

VANDEnBerg A. H. M. \& COOPER R. A. 1992. The Ordovician graptolite sequence of Australasia. Alcheringa 16, 33-85.

VerbeEten A. 1997. Petrology, geochemistry and tectonic implications of magmatism along the northern Hunter Ridge and Kadavu Island Group, Fiji. PhD thesis, University of Tasmania, Hobart (unpubl.).

Waight T. E., Weaver S. D., Muir R. J., MaAs R. \& Eby G. N. 1998. The Hohonu Batholith of North Westland, New Zealand: granitoid compositions controlled by source $\mathrm{H}_{2} \mathrm{O}$ contents and generated during tectonic transition. Contributions to Mineralogy and Petrology 130, 225-239.

WATSON E. B. \& GREEN T. B. 1981. An experimental determination of primary carbonatite magma composition. Nature 355, 343346.

Whelan P. M., Gill J. B., Kollman E., Duncan R. A. \& Drake R. E. 1985. Radiometric dating of magmatic stages in Fiji. In: Scholl D. W. \& Vallier T. L. eds. Geology and Offshore Resources of Pacific Island Arcs: Tonga Region, vol. 2, pp. 415-440. CircumPacific Council for Energy and Mineral Resources, Houston.

WiLliams I. S. 1998. U-Th-Pb geochronology by ion microprobe. In: McKibben M. A., Shanks W. C. III \& Ridley W. I. eds. Applications of Microanalytical Techniques to Understanding Mineralizing Processes, pp. 1-35. Reviews in Economic Geology 7.

WyBORN D. 1992. The tectonic significance of Ordovician magmatism in the eastern Lachlan Fold Belt. Tectonophysics 214, 177-192.

WyBORN D. \& HENDERSON G. A. M. 1996. Notes accompanying geological map Blayney 1:100 000 Sheet area. Australian Geological Survey Organisation Record 1996/56.

WYBORN D. \& SUN S-S. 1993. Nd-Isotopic 'fingerprinting' of the $\mathrm{Cu} / \mathrm{Au}$ mineralisation in the Lachlan Fold Belt. AGSO Research Newsletter 19, 13-14.

Yu Z., ROBINSON P. \& MCGoLDRICK P. 2001. An evaluation of methods for the chemical decomposition of geological materials for trace element determination using ICP-MS. Geostandards Newsletter 25, 199-217.

Received 30 April 2004; accepted 25 October 2006

\section{SUPPLEMENTARY PAPERS}

APPENDIX 1: LOCATIONS AND RESULTS OF A REPRESENTATIVE SUBSET OF XRF ANALYSES APPENDIX 2: LOCATIONS AND RESULTS OF ICP-MS ANALYSES 